Article

\title{
Untargeted Analysis for Mycosporines and Mycosporine-Like Amino Acids by Hydrophilic Interaction Liquid Chromatography (HILIC)-Electrospray Orbitrap $\mathrm{MS}^{2} / \mathrm{MS}^{3}$
}

\author{
Maroussia Parailloux *, Simon Godin, Susana C. M. Fernandes and Ryszard Lobinski \\ IPREM, UMR 5254, E2S UPPA, CNRS, Universite de Pau et des Pays de l'Adour, 64000 Pau, France; \\ simon.godin@univ-pau.fr (S.G.); susana.fernandes@univ-pau.fr (S.C.M.F.); ryszard.lobinski@univ-pau.fr (R.L.) \\ * Correspondence: m.parailloux@univ-pau.fr
}

Received: 28 October 2020; Accepted: 20 November 2020; Published: 26 November 2020

\begin{abstract}
Mycosporines and mycosporine-like amino acids have been described as natural sunscreens and antioxidant compounds presenting a great potential for health and cosmetic applications. Herein, an untargeted screening approach for mycosporines and mycosporine-like amino acids (MAAs) was developed by the coupling of zwitterionic hydrophilic interaction liquid chromatography (HILIC) with multistage electrospray mass spectrometry $\mathrm{MS}^{2} / \mathrm{MS}^{3}$ using an Orbitrap analyzer and fragment ion search (FISh). This method was applied to study the mycosporine and MAA contents of five algae extracted using a 50\% methanol solution and sonication. Candidate-MAAs were detected by mining eight characteristic fragment ions in their HILIC data-dependent $\mathrm{MS}^{2}$ mass spectrum. Their exact masses were measured with $3 \mathrm{ppm}$ mass accuracy and their structures were elucidated on the basis of the $\mathrm{MS}^{3} / \mathrm{MS}^{4}$ mass spectra. The method developed was validated with a targeted analysis using an extract of Gymnogongrus devoniensis which confirmed the detection of 14 MAAs reported in the literature. In addition, 23 previously unreported MAAs were detected and the structures could be assigned for seven of them. The developed method was applied to the analysis of four algae: Gelidium sesquipedale, Halopithys incurva, Porphyra rosengurtii and Cystoseira tamariscifolia allowing the detection of MAAs, including some reported here for the first time.
\end{abstract}

Keywords: algae; mycosporines; mycosporine-like amino acids; high resolution mass spectrometry; fragment ion search; untargeted screening

\section{Introduction}

Algae inhabiting the intertidal zones with an extensive sun-exposure cope with UV-induced oxidative stress by the synthesis of potent photoprotectants including pigments, phenolic compounds and mycosporine-like amino acids (MAAs) [1]. These water-soluble and small-sized compounds $(<500 \mathrm{Da})$ exhibit strong UV-absorbing properties (molar absorption coefficients $\varepsilon$ reaching $50,0001 . \mathrm{M}^{-1} \cdot \mathrm{cm}^{-1}$ ) [2]. In the cells, they act mainly as scavengers of radical oxygen species (ROS), prevent lipid oxidation and quench UVB $(280-315 \mathrm{~nm})$ and UVA $(315-360 \mathrm{~nm})$ radiations without generating oxidative photoproducts [3,4]. These characteristics make MAAs attractive natural products to replace mineral and synthetic UV-filters (sunscreens) in cosmetics and, to be used in UV-protective additives in contact lenses, outdoor materials, textiles, food and drug packaging, and coatings [2,5-8].

MAAs are usually classified in five main families [9] based on their amino-substituent on the $\mathrm{C} 3$ as shown in Table 1.

Mycosporines differ from MAAs by the presence of a ketone instead of an imino-group on the $C_{1}$ of their skeleton ring, hence their naming oxo- and imino-MAAs in the literature $[9,10]$. Please note 
that the glycine on the $C_{3}$ [10] can be replaced by serine, glutamine or glutamic acid to constitute three atypical MAA subfamilies. In marine micro- and macro-algae, MAAs belong mainly to the palythine and glycine families [9]. MAAs containing sulfate esters such as e.g., mycosporine-taurine or palythine-serine-sulfate, and glycosidic linkages were also identified in cyanobacteria, diatoms, corals and anemones [9-11].

The studies of MAAs were originally based on high-performance liquid chromatography (HPLC) using diode array detection (DAD) making use of their high molar absorption coefficient [12-14] and the dependence of the absorption wavelength on their amino-cyclohexenimine ring (imino-MAAs, $\lambda \max 360 \mathrm{~nm}$ ) or their amino-cyclohexenone ring (mycosporine or oxo-MAAs, $\lambda \max 310 \mathrm{~nm}$ ) [10]. The identification of the substituent functional groups could be achieved only after chromatographic purification of the individual MAAs followed by their analysis by nuclear magnetic resonance (NMR) and tandem mass spectrometry (ESI-MS ${ }^{\mathrm{n}}$ ) analysis. ${ }^{2} \mathrm{H}$ [15] and ${ }^{13} \mathrm{C}$ [16] NMR was used for the MAA structure elucidation. Moreover, an ESI-MS ${ }^{2}$ method was developed with hydrogen/deuterium exchange to elucidate unambiguously the MAA structures [17,18].

The isolation and structure elucidation allowed the indexation of over 20 MAAs with their molecular mass, structures, UV-Vis absorption properties and concentrations in more than 500 algal species in the literature and online databases [19]. Reference standards for some of them have been made available which allows their identification on the basis of the retention time using HPLC with diode array (DAD) [14,20-22] or quadrupole (Q) ESI-MS detection [10]. Standardless identification requires the on-line detection either by ion-trap $\mathrm{MS}^{2} / \mathrm{MS}^{3}$ or $[21] \mathrm{Q}-\mathrm{TOF}[15,16,23]$ or high resolution $(>100,000)$ high mass accuracy $(<5$ ppm) (HRAM) MS. The LC-MS methods used previously and the MAAs identified to date are summarized in Table 2. 
Table 1. Classification of mycosporines, MAAs and their precursor reported in the literature. The structure and the theoretical monoisotopic mass (Da) were detailed for every compound classified in five families depending on their amino acid substituents on the C3. The structural relationships were briefly described for every example [9].

\begin{tabular}{|c|c|c|c|c|c|}
\hline MAA Family & Precursor & Serine Family & Glutamine Family & Palythine Family & Glutamic Acid Family \\
\hline Name & $\begin{array}{l}\text { 4-deoxygadusol } \\
\text { (4-DG) }\end{array}$ & $\begin{array}{l}\text { Mycosporine-serinol } \\
\text { (M-SerOH) }\end{array}$ & $\begin{array}{l}\text { Mycosporine-glutamine } \\
\text { (M-Gln) }\end{array}$ & $\begin{array}{c}\text { Palythine } \\
\text { (PNE. M-NH2:Gly ) }\end{array}$ & $\begin{array}{c}\text { Mycosporine-glutamic } \\
\text { acid } \\
\text { (M-Glu) }\end{array}$ \\
\hline Structure & & $?_{\mathrm{OH}}$ & $\mathrm{OH}$ & & \\
\hline Monoisotopic mass (Da) & 188.0685 & 261.1212 & 316.1271 & 244.1059 & 317.1111 \\
\hline Structural relationships & Reduction of Gadusol & $\begin{array}{l}\text { Reduction of } \\
\text { M-Ser }\end{array}$ & $\begin{array}{l}4-\mathrm{DG}+\mathrm{Gln} \rightarrow \\
\mathrm{M}-\mathrm{G} \ln +\mathrm{H}_{2} \mathrm{O}\end{array}$ & $\begin{array}{c}4-\mathrm{DG}+\mathrm{NH}_{2}+\mathrm{Gly} \rightarrow \\
\mathrm{M}-\mathrm{NH}_{2}: \mathrm{Gly}+\mathrm{H}_{2} \mathrm{O}\end{array}$ & $\begin{array}{l}4-\mathrm{DG}+\mathrm{Glu} \rightarrow \\
\mathrm{M}-\mathrm{Glu}+\mathrm{H}_{2} \mathrm{O}\end{array}$ \\
\hline MAA Family & & & Glycine Family & & \\
\hline Subfamily & $\begin{array}{l}\text { Glycine } \\
\text { Subfamily }\end{array}$ & $\begin{array}{l}\text { Serine } \\
\text { Subfamily }\end{array}$ & $\begin{array}{l}\text { Valine } \\
\text { Subfamily }\end{array}$ & Threonine Subfamily & $\begin{array}{l}\text { Alanine } \\
\text { Subfamily }\end{array}$ \\
\hline Name & $\begin{array}{c}\text { Asterina-330 } \\
\text { (Ast. M-Gly:Gly }(\mathrm{OH}) \text { ) } \\
\text { HO }\end{array}$ & $\begin{array}{l}\text { Shinorine (SH) } \\
\text { (M-Gly:Ser) } \\
\end{array}$ & $\begin{array}{l}\text { Mycosporine-glycine-valine } \\
\text { (M-Gly:Val) }\end{array}$ & $\begin{array}{l}\text { Porphyra-334 } \\
\text { (P-334. M-Gly:Thr) }\end{array}$ & $\begin{array}{l}\text { Palythinol (Pinol) } \\
\text { (M-Gly:Ala }(\mathrm{OH})) \\
\mathrm{HO}\end{array}$ \\
\hline \multicolumn{6}{|l|}{ Structure } \\
\hline Monoisotopic mass (Da) & 288.1321 & 332.1219 & 344.1583 & 346.1376 & 302.1478 \\
\hline Structural relationships & Reduction of M-2Gly & $\begin{array}{c}\text { M-Gly + Ser } \rightarrow \\
\text { M-Gly:Ser }+\mathrm{H}_{2} \mathrm{O}\end{array}$ & $\begin{array}{c}\text { M-Gly + Val } \rightarrow \\
\text { M-Gly:Val + } \mathrm{H}_{2} \mathrm{O}\end{array}$ & $\begin{array}{c}\text { M-Gly }+\mathrm{Thr} \rightarrow \\
\text { M-Gly:Thr }+\mathrm{H}_{2} \mathrm{O}\end{array}$ & $\begin{array}{l}\text { M-Gly }+ \text { Ala } \rightarrow \\
\text { M-Gly:Ala }+\mathrm{H}_{2} \mathrm{O} \\
\text { (2) Reduction of } \\
\text { M-Gly:Ala }\end{array}$ \\
\hline
\end{tabular}


Table 2. Inventory of MAAs identified in targeted HPLC-ESI-MS methods operated in positive mode.

\begin{tabular}{|c|c|c|c|c|c|}
\hline Marine Organisms & $\begin{array}{l}\text { Number of } \\
\text { MAAs }\end{array}$ & MAAs & HPLC Conditions & MS Analysis & Literature \\
\hline $\begin{array}{l}\text { Brostrychia scorpioides. Porphyra } \\
\text { dioica. Gracilaria vermiculophylla. } \\
\text { Vertebrata lanosa (Red Algae) }\end{array}$ & 6 & $\begin{array}{l}\text { Shinorine. palythine. asterina- } 330 \text {. } \\
\text { porphyra-334. usijirene. palythene. }\end{array}$ & $\begin{array}{l}\text { Reversed-phase chromatography } \\
\text { ACE C18 column }(150 \times 4.6 \mathrm{~mm} ; 3 \mu \mathrm{m})\end{array}$ & $\begin{array}{c}\text { Q-TOF } \\
\text { Resolution 20.000 FWHM } \\
\text { Full MS scan range: } \\
m / z 50-1000\end{array}$ & $\begin{array}{l}\text { Lalegerie et al. } \\
\quad(2019)[22]\end{array}$ \\
\hline $\begin{array}{l}\text { Rhodymenia pseudopalmata } \\
\text { (Red Alga) }\end{array}$ & 8 & $\begin{array}{l}\text { Deoxygadusol. porphyra-334. shinorine. } \\
\text { palythine. asterina-330. palythinol. usijirene. } \\
\text { palythene. }\end{array}$ & $\begin{array}{l}\text { Reversed-phase chromatography } \\
\text { Luna Omega C18 }(250 \times 4.6 \mathrm{~mm} ; 5 \mu \mathrm{m})\end{array}$ & $\begin{array}{c}\text { Q-TOF } \\
\text { Resolution 20.000 FWHM } \\
\text { Full MS scan range: } \\
m / z 100-1000\end{array}$ & $\begin{array}{l}\text { Pliego-Cortès et } \\
\text { al. (2019) [24] }\end{array}$ \\
\hline Oscilatoria sp. (Cyanobacteria) & 13 & $\begin{array}{l}\text { Palythine. shinorine. porphyra-334. } \\
\text { palythine-serine. palythine threonine. } \\
\text { mycosporine-glycine. mycosporine-taurine. } \\
\text { mycosporine-ornithine. hexose-bond } \\
\text { palythine-serine and hexose-bond } \\
\text { palythine-threonine. }\end{array}$ & $\begin{array}{c}\text { Reversed-phase chromatography } \\
\text { Synergi Hydro-RP } 80 \mathrm{~A} \text { column }(150 \times \\
2.0 \mathrm{~mm} ; 4 \mu \mathrm{m})\end{array}$ & $\begin{array}{c}\text { Q-TOF } \\
\text { Resolution 20.000 FWHM } \\
\text { Full MS scan range: } \\
m / z \text { 50-500 } \\
\text { MS/MS: Top3 } \text { MS }^{2}\end{array}$ & $\begin{array}{l}\text { Geraldes et al. } \\
\text { (2019) [23] }\end{array}$ \\
\hline Catenella repens. (Red Alga) & 1 & 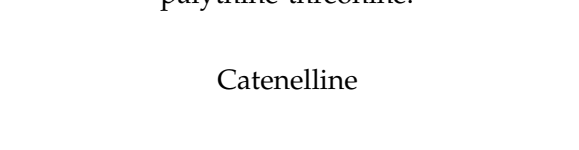 & $\begin{array}{l}\text { HILIC chromatography } \\
\text { Sequant ZIC-HILIC }(250 \mathrm{~mm} \times 4.6 \mathrm{~mm} ; \\
5 \mu \mathrm{m})\end{array}$ & $\begin{array}{l}\text { Q-TOF } \\
\text { Ion-trap } \\
\text { Full MS scan range: } \\
\text { m/z 100-1500 }\end{array}$ & $\begin{array}{l}\text { Hartmann et al. } \\
\text { (2015) [15] }\end{array}$ \\
\hline Microalgae & 5 & $\begin{array}{l}\text { Palythene. palythine. mycosporine-glycine. } \\
\text { palythenic-acid. porphyra-334. shinorine. }\end{array}$ & $\begin{array}{l}\text { Normal-phase chromatography } \\
\text { Luna NH2 column }(250 \times 4.6 \mathrm{~mm} ; \\
5 \mu \mathrm{m})\end{array}$ & $\begin{array}{l}\text { Ion-trap } \\
\text { MS }^{3} \text { scans }\end{array}$ & $\begin{array}{l}\text { Llewellyn and } \\
\text { Airs (2010) [13] }\end{array}$ \\
\hline Palmaria palmata (Red Alga) & 6 & $\begin{array}{l}\text { Palythine. shinorine. asterina- } 330 . \\
\text { palythinol. porphyra-334. Usujirene }\end{array}$ & $\begin{array}{l}\text { Reversed-phase chromatography } \\
\text { Inertsil ODS-3 column }(250 \mathrm{~mm} \times \\
4.6 \mu \mathrm{m} ; 5 \mu \mathrm{m})\end{array}$ & $\begin{array}{c}\text { Ion-trap } \\
\text { MS scan: } m / z \text { 50-600 }\end{array}$ & $\begin{array}{c}\text { Yuan et al. (2009) } \\
\text { [21] }\end{array}$ \\
\hline Pocillopora capitata (Coral) & 12 & $\begin{array}{l}\text { Palythine-serine-sulfate. mycosporine } \\
\text { sulfate. shinorine. mycosporine-2-glycine. } \\
\text { palythine-serine. palythine. porphyra-334. } \\
\text { mycosporine-methylamine-serine. } \\
\text { mycosporine-glycine. } \\
\text { palythine-threonine. palythinol. } \\
\text { mycosporine-methylamine-threonine. }\end{array}$ & $\begin{array}{l}\text { Reversed-phase chromatography } \\
\text { C18 column }(4.6 \times 150 \mathrm{~mm} ; 3 \mu \mathrm{m})\end{array}$ & $\begin{array}{l}\text { Ion-trap. TOF } \\
\text { Resolution } 10.000 \\
\mathrm{MS}^{2} / \mathrm{MS}^{3} \text { scans }\end{array}$ & $\begin{array}{l}\text { Carignan et al. } \\
\text { (2009) [18] }\end{array}$ \\
\hline
\end{tabular}


The use of HRAM detection has been scarce; the only example is the use of Orbitrap MS in full MS mode to identify five MAAs in two red algae Hydropuntia cornea and Gracilaria longissima [25].

The diversity of the identified MAA structures make plausible the hypothesis that many more still remain to be discovered. The exhaustive information on the MAA diversity is crucial for the prediction of UV-filtering properties of algal extracts and the wider use of algae in cosmetic, biomedical, and industrial fields. It can be obtained by untargeted MS allowing the discovery of unreported MAAs. Hence, the purpose of this research was to develop a HRAM multistage mass spectrometry method and the related data mining strategies for the analysis for MAAs.

\section{Materials and Methods}

\subsection{Biological Materials, Chemicals and Reagents}

Purified MAAs, namely shinorine (Gymnogongrus devoniensis), palythine (from Asparragopsis armata), porphyra-334 (from Porphyra rosengurtii), and mycosporine-serinol (from Lichina pygmaea lichen), were purchased from the Laboratory of Photobiology of the Central Research Services of the University of Malaga (Spain) and stored at $-20^{\circ} \mathrm{C}$. The algae and lichen were collected in 2018 and 2019 in the Andalusian coast (Spain).

Among the five algal concentrated extracts analyzed, two were provided by the laboratory described above, namely lyophilized algal powders from Gymnogongrus devoniensis and Porphyra rosengurtii; and the other three were extracted in-house (as described below) from two fresh red algal species (Gelidium sesquipedales, Halopithys incurva) and one fresh brown algal specie (Cystoseira tamariscifolia) collected in November 2018 in the intertidal zone of Les Viviers Basques at Hendaye (France) and stored at $-80^{\circ} \mathrm{C}$.

Solutions of purified MAAs were prepared at $5 \mu \mathrm{g} . \mathrm{mL}^{-1}$ in $1.5 \%$ methanol and $0.5 \%$ acetic acid. Algal concentrated extracts were prepared by extraction with water from stock lyophilized powders of the algae Gymnogongrus devoniensis ( $58 \mathrm{mg} \cdot \mathrm{mL}^{-1}$ ) and Porphyra rosengurtii $\left(22 \mathrm{mg} . \mathrm{mL}^{-1}\right)$. As mentioned before, concentrated extracts from fresh algae were prepared in-house. Briefly, all fresh algae were freeze-dried and crushed using a grinding mill. Afterwards, $500 \mathrm{mg}$ were extracted with $50 \%$ methanol solution over $30 \mathrm{~min}$ in an ultrasonic bath and the crude extracts were ultracentrifuged at 50,000 rpm during $20 \mathrm{~min}$. Then, the supernatants were stored at $-20^{\circ} \mathrm{C}$. Every supernatant was diluted 500 -fold with mobile phases ( $5 \mathrm{mM}$ ammonium acetate in $90 \%$ acetonitrile) before filtration using a $0.22-\mu \mathrm{m}$ nylon membrane syringe filter. Exposure to direct sunlight was avoided as much as possible over the sample preparation.

Methanol and acetonitrile used for extraction and analytical experiments were LC-MS grade and purchased from Honeywell (Morris Plains, NJ, USA). Ammonium acetate, acetic acid and deuterium were LC-MS grade and purchased from Sigma Aldrich (L'Isle D'Abeau Chesnes, France). Ultrapure water was obtained from a Direct-Q3 UV (Merck, Fontenay-sous-Bois, France).

\section{Instrumentation}

Analysis of MAAs was carried out using an Ultimate 3000 RSLC system (ThermoFisher Scientific, Bremen, Germany) coupled with an Orbitrap Fusion Lumos Tribrid mass spectrometer (ThermoFisher Scientific, Waltham, MA, USA) operated in positive mode. Fraction collection of algal extracts and infusion of MAAs were performed with a TriVersa NanoMate (Advion BioSciences, Ithaca, NY, USA) fitted on the Orbitrap Fusion Lumos instead of the standard ESI source.Data treatment for the inventory of known MAAs and characterization novel structures was carried out on Compound Discoverer 2.1 $1^{\mathrm{TM}}$ (ThermoFisher Scientific, Waltham, MA, USA). The tracking of neutral and radical losses and structural prediction of novel MAAs were carried out on Mass Frontier 7.0 ${ }^{\mathrm{TM}}$ (HighChem, Bratislava, Slovakia). 


\subsection{Methods}

\subsubsection{Chromatographic Conditions}

The separation of MAAs was carried out on a SeQuant@ZIC-cHILIC $(150 \times 2.1 \mathrm{~mm}, 3 \mu \mathrm{m}, 100 \AA)$ (Merck, Fontenay-sous-Bois, France). The mobile phases were: $5 \mathrm{mM}$ ammonium acetate in water at pH 6.7 (A) and acetonitrile (B). The HPLC separation was carried out with the following gradient elution profile: $0-2 \mathrm{~min}, 10 \% \mathrm{~B} ; 2-13 \mathrm{~min}, 10$ to $40 \% \mathrm{~B} ; 13-15 \mathrm{~min}, 40$ to $60 \% \mathrm{~B}$; $15-17 \mathrm{~min}, 60 \% \mathrm{~B}$; $17-19 \mathrm{~min}, 60$ to $10 \% \mathrm{~B} ; 19-24 \mathrm{~min}, 10 \% \mathrm{~B}$. A $20 \mu \mathrm{L}$ aliquot of diluted extract was injected.

\subsubsection{Untargeted Screening of MAAs}

The purified MAAs palythine, porphyra-334, shinorine and mycosporine-serinol were infused at $50 \mathrm{ng} . \mathrm{mL}^{-1}$ at the flow rate $5 \mu \mathrm{L} . \mathrm{min}^{-1}$. Two fragmentation modes (collision-induced dissociation (CID ) and higher-energy C-trap dissociation (HCD)) were applied at different collision energies (30, 50, 70, 90 and 110). The CID parameters were: activation time at $10 \mathrm{~ms}$ and activation Q at 0.25 . The ESI parameters were set: sheath gas at 5 (arb), auxiliary gas at $0(\mathrm{arb})$, sweep gas at 0 (arb) and ion transfer tube temperature at $275^{\circ} \mathrm{C}$.

Figure 1a shows the scan events set in the acquisition method of the mass spectrometer.

(a)

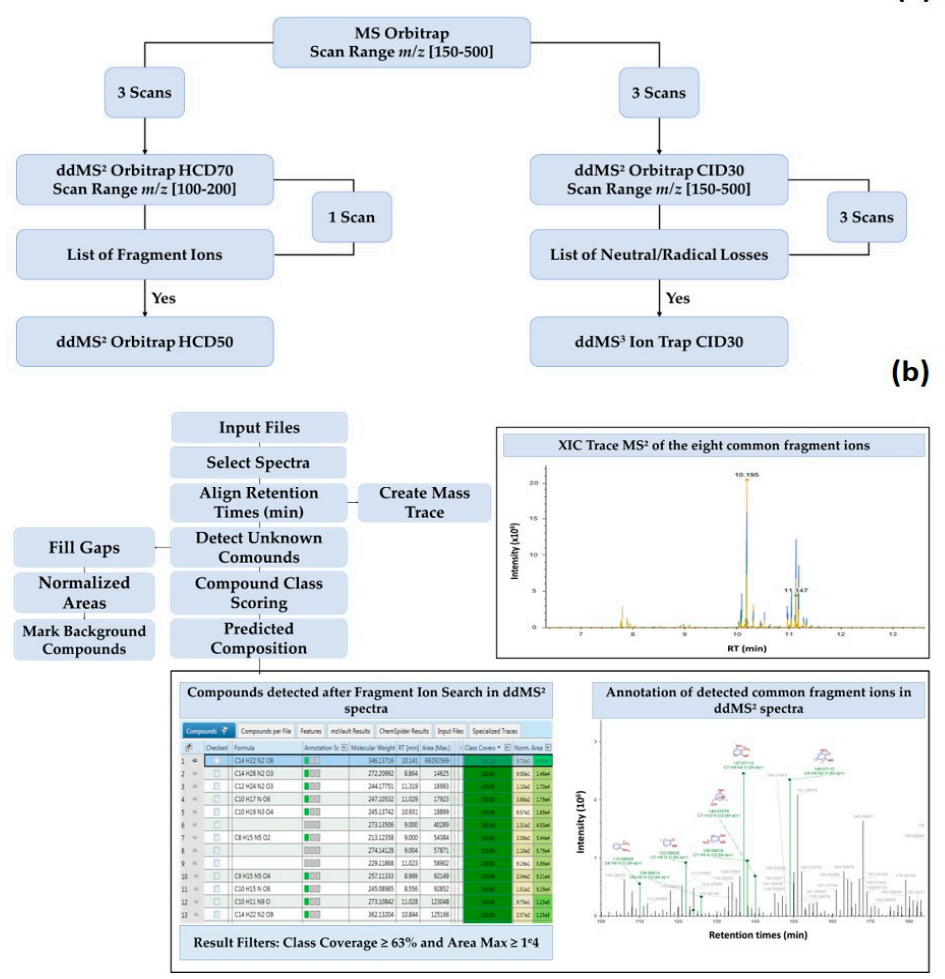

Figure 1. Flowchart of the developed untargeted screening approach of MAAs using an Orbitrap MS based on data-dependent $\mathrm{MS}^{2} / \mathrm{MS}^{3}$ Acquisition (a). Untargeted workflow designed on Compound Discoverer ${ }^{\mathrm{TM}}$ to flag putative MAAs in algal extracts $(\mathbf{b})$. Description of the role of the following nodes: Compound Class Scoring: Calculation of the percentage of common fragment ions detected in mass spectral data of every compound in the result table. Predicted Composition: Proposition of chemical formula for unknown compounds. Create mass Trace: Create mass chromatogram of compounds for which common fragment ions were detected in their mass spectral data. Fill Gaps: Indication of missing peaks or peaks below the detection threshold. Normalize Areas: Normalization of chromatographic peaks. Mark Background Compounds: Identification of compounds in blanks. 
For LC-MS experiments, the ESI conditions were: sheath gas 50 (arb), auxiliary gas 10 (arb), sweep gas $1(\mathrm{arb})$, ion transfer tube and vaporizer temperature $350{ }^{\circ} \mathrm{C}$, rf lens $50 \%$ and positive ionization voltage 3500 V. Full MS Orbitrap (OT) settings were: resolution 140,000, mass range $m / z 150-500$, dynamic exclusion $5 \mathrm{~s}$ and intensity threshold $2 \times 10^{4}$. The ddMS ${ }^{2}$ OT settings were: resolution 60,000 for HCD70 MS/MS scans and 30,000 for HCD50 and CID30 MS/MS scans, isolation width $2 \mathrm{Da}$. The ddMS ${ }^{3}$ ion-trap (IT) settings were: scan rate 33,333 Da/s, peak width $\leq 0.5 \mathrm{FWHM}$, isolation width $2 \mathrm{Da}$. HCD70 MS ${ }^{2}$ scans with a scan range set to $100-200 \mathrm{~m} / z$ were used to produce common fragment ions and CID30 MS ${ }^{2}$ was used to generate both neutral losses and small radicals. The common fragment ions were listed in the first filter permitting the triggering of further ddMS $^{2}$ HCD50 scans for structural elucidation of candidate-MAAs. Likewise, neutral and small radical losses were included in the second filter triggering a ddMS ${ }^{3}$ CID30 to confirm the detection of the candidate-MAAs found in parallel with the common fragment ions.

Compound Discoverer $2.1^{\mathrm{TM}}$ software was applied to mine and identify the MAA contents in every extract in targeted and untargeted approach. The workflow illustrated in Figure $1 \mathrm{~b}$ was designed for the untargeted analysis with a mass tolerance at $5 \mathrm{ppm}$ and a minimum peak intensity at $1 \times 10^{4}$. The retention time tolerance was fixed at $0.2 \mathrm{~min}$ and the signal/noise ratio at 20 . To make the inventory of compounds with at least the number of elements corresponding to the skeleton core of MAAs, a minimum element threshold was defined with the molecular formula $\mathrm{C}_{6} \mathrm{H}_{14} \mathrm{O}_{2}$. Likewise, a maximum element threshold was set with $\mathrm{C}_{90}, \mathrm{H}_{180}, \mathrm{O}_{50}, \mathrm{~N}_{50}$ and $\mathrm{S}_{10}$ to cover amino-cyclohexenones, amino-cyclohexenimines and eventually sulfated MAAs. The Compound Class Scoring node scores and annotates ions corresponding to the set of common fragment ions in HCD70 MS 2 OT scans of detected compounds. A minimum number of five fragment ions were used to consider a positive MAAs flagging. The Create Mass Trace node plotted a XIC trace showing retention times of compounds for which the set of fragment ions were detected in HCD70 MS ${ }^{2}$ OT scans.

\subsubsection{Validation by Targeted Screening of MAAs}

A Top3 MS $^{2}$ analysis was carried out to make the inventory of MAAs in the model algal extract Gymnogongrus devoniensis as described in Figure S1a. The Full MS Orbitrap (OT) settings were: resolution 140,000, mass range $m / z 150-500$, dynamic exclusion $5 \mathrm{~s}$ and intensity threshold $2 \times 10^{4}$. The MS ${ }^{2}$ scans settings were: HCD50 resolution 60,000, stepped collision energy $+/-20$, isolation width $2 \mathrm{Da}$. For every detected mass, a FISh score was calculated to estimate the percentage of fragment ions generated in silico matching with the collected spectral data. A description of the targeted screening workflow designed on Compound Discoverer in Figure S1b.

\subsubsection{Identification of Novel MAAs}

Fraction collection of algal extracts was performed to re-analyze by infusion the MAAs for which the structure needed to be confirmed or elucidated. The ion source of the Orbitrap Fusion Lumos was replaced by the Triversa Nanomate (on-chip nano ESI system). The latter was operated in LC chip coupling with fraction collection mode, a split setting allowing a flow of $380 \mathrm{~nL}$. $\mathrm{min}^{-1}$ on the HD-A ESI-chip was used (remaining flow was sent to waste or to fraction collection mandrel depending on retention time). An LC coupler (Advion P/N 1003236) was used to deliver the flow on the chip. 30-s fractions were collected in a pre-washed 96 wells Advion plate from 7 to $13 \mathrm{~min}$ in the LC gradient. The electrospray voltage was fixed at $+1.4 \mathrm{kV}$.

Algal extract fractions collected with the TriVersa NanoMate were re-analyzed in infusion mode by multistage fragmentation. $\mathrm{MS}^{3} / \mathrm{MS}^{4}$ spectra were acquired in positive mode at CID30, CID50, CID70, HCD30 and HCD50. The CID parameters were activation time at $10 \mathrm{~ms}$ and activation $\mathrm{Q}$ at 0.25 . Off-line analyses of fractions were carried out with an electrospray voltage of $+1.4 \mathrm{kV}$ and a backing gas pressure of $0.8 \mathrm{psi}$. Ion transfer tube temperature was set at $275^{\circ} \mathrm{C}$. 


\subsubsection{Quantitative Analysis of MAAs}

The MAAs porphyra-334, shinorine and palythine were quantified in the model algae Gymnogongrus devoniensis using the standard addition method. The spiked extracts were analyzed in targeted SIM (isolation width $1 \mathrm{~min}$, resolution 60,000). Amounts of standardless MAAs were estimated assuming an absorption coefficient $(\varepsilon)$ equal to the mean of the absorption coefficients of the three purified MAAs.

\section{Results and Discussion}

\subsection{Extraction of MAAs in Fresh Algal Samples}

The polarity and the low molecular weight make MAAs readily extractable with methanol. The employed concentrations varied from 20 to $100 \%$ with controversies of the methanol concentration on the recovery $[12,15,23,26]$. No particular effect of the methanol concentration was observed in this study; therefore a $50 \%$ methanol solution and sonication were used to extract the MAAs from fresh algal samples. The use of ethanol proposed elsewhere [22] resulted in lower recoveries.

\subsection{Chromatographic Conditions}

Three different stationary phases were investigated to achieve the best separation of MAAs: a reversed phase UPLC BEH C18 column $(2.1 \mathrm{~mm} \times 150 \mathrm{~mm}, 1.7 \mu \mathrm{m}$, Waters), a HILIC Kinetex HPLC column $(100 \times 2.1 \mathrm{~mm}, 2.6 \mu \mathrm{m}, 100 \AA$ A Phenomenex $)$ and a zwitterionic SeQuant $囚 Z I C-c H I L I C$ column $(150 \times 2.1 \mathrm{~mm}, 3 \mu \mathrm{m}, 100 \AA)$. The two latter HILIC columns differ in terms of their stationary phase one being silica diol groups and the other one functionalized silica with phosphoryl-choline groups. The optimization of the HPLC conditions was carried out by searching for the accurate mass of MAAs known in the literature in a full MS analysis of the model algae Gymnogongrus devoniensis. The latter was selected because of its richness of compounds. The separation performance of the three columns were compared regarding the number of MAAs efficiently retained and separated.

The first results showed the MAAs were not retained on the UPLC BEH C18 column using a gradient elution with $0.1 \%$ of formic acid in acetonitrile/water. The chromatographic method proposed elsewhere [12] to separate strongly acidic, neutral MAAs and the isomeric couple cis-usujirene and trans-palythene using acetonitrile-based eluents and polymeric double endcapped C18 columns turned out to be insufficient to separate highly polar compounds. The use of the HILIC Kinetex HPLC column improved the retention of high polar MAAs on the stationary phase but did not allow a satisfactory resolution and symmetric peaks. An alternative method based on the zwitterionic properties of MAAs using a Zic-HILIC column improved their separation [15]. As is shown in Figure 2, 14 MAAs were efficiently retained on the SeQuant@ZIC-cHILIC column and identified in the full MS scan with a mass error lower or equal to $3 \mathrm{ppm}$. The same separation method was performed on four other algal extracts for which MAA-profiles were detailed in Figure S2a-d.

The separation efficiency of MAAs and their ionization conditions were optimized using ammonium acetate solution at $5 \mathrm{mM}$ and $\mathrm{pH} 6.5[14,15]$. In these conditions, 14 candidate-MAAs were separated between 7 and $12 \mathrm{~min}$.

As it was discussed elsewhere, coelution was observed in almost all the separation procedures of MAAs owing to the presence of several isomers. Moreover, the disparity of their polarity made it more difficult to choose an efficient column retaining all the MAAs without coelution $[10,12]$. With the increasing number of MAAs accounted for, coelutions cannot be avoided and the HRAM MS detection, which allows the resolution of all the MAAs except the mass isomers, is mandatory. The separation of isomers has to be addressed by multistage MS $^{\mathrm{n}}$ analysis. 

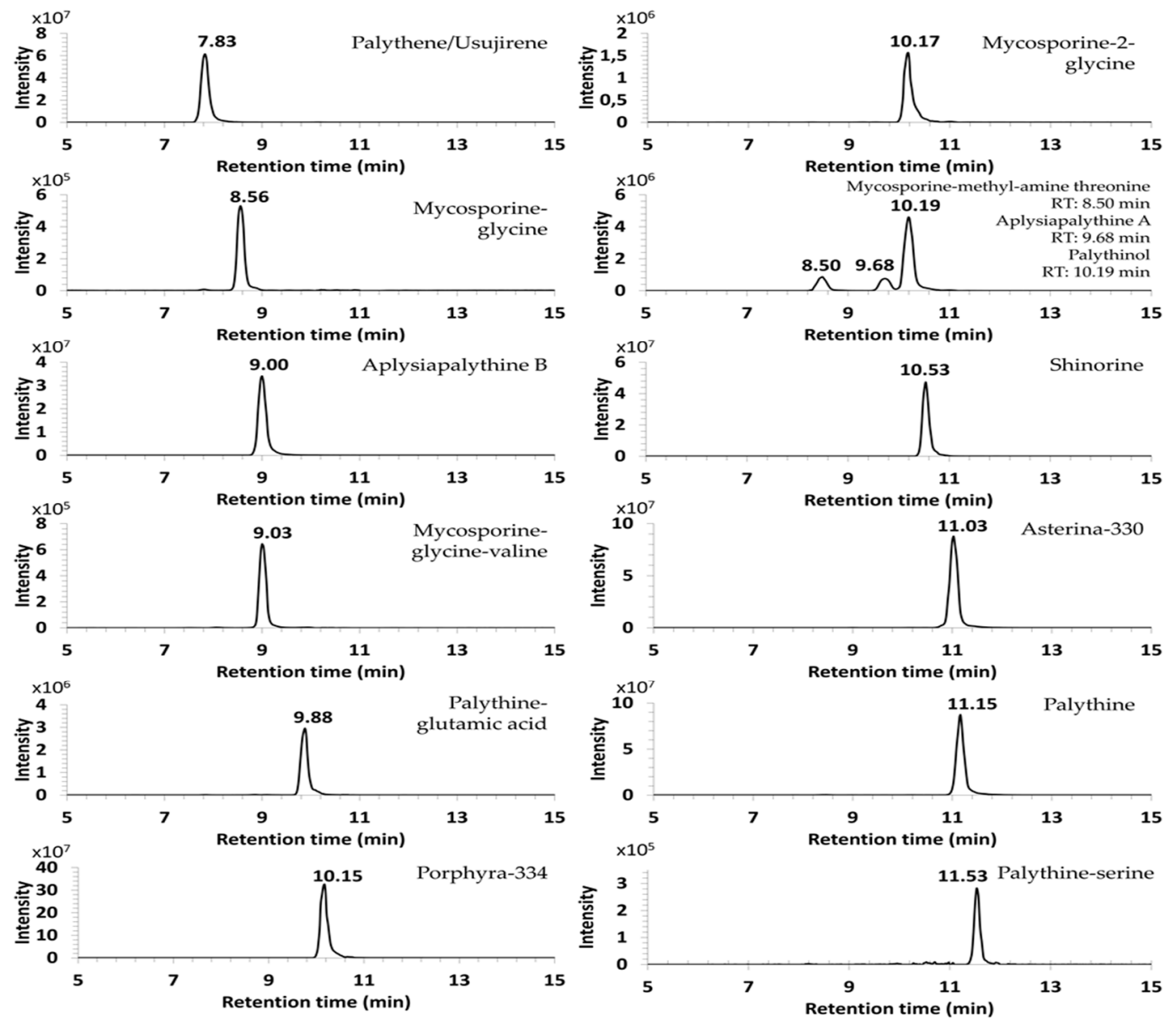

Figure 2. XIC of MAAs (3ppm) in Gymnogongrus devoniensis separated on the Zic-cHilic column. Palythene/Usujirene: $m / z$ 285.1440, error -1.75 ppm; Mycosporine-glycine: $m / z$ 246.0971, error -0.41 ppm; Aplysiapalythine B: $m / z$ 273.1436, error -3.3 ppm; Mycosporine-glycine-valine: $m / z$ 345.1653, error -2.06 ppm; Palythine-glutamic-acid: $m / z$ 317.1338, error -1.58 ppm; Porphyra-334: m/z 347.1447, error -0.86 ppm; Mycosporine-2-glycine: m/z 303.1185, -0.66 ppm; Mycosporine methyl-amine threonine: $\mathrm{m} / \mathrm{z}$ 303.1549, error $-0.66 \mathrm{ppm}$; Aplysiapalythine A: $\mathrm{m} / \mathrm{z} 303.1542$, error -2.97 ppm; Palythinol: $m / z$ 303.1548, error -0.66 ppm; Shinorine: $m / z$ 333.1286, error -1.8 ppm; Asterina-330: $m / z$ 289.1389, -1.73 ppm; Palythine: $m / z$ 245.1123, error -2.85 ppm; Palythine-serine: $\mathrm{m} / \mathrm{z} 275.1234$, error $-1.45 \mathrm{ppm}$.

\subsection{Identification of Cancidate-MAAs in Untargeted Analysis}

\subsubsection{Fragmentation Pathways of MAAs}

The goal was to investigate the fragmentation patterns of MAAs in order to define a set of characteristic fragment ions, neutral and radical losses to serve the untargeted detection of MAAs and to find the optimal conditions to generate these fragments. For this purpose, several levels of collision energies were tested on three purified imino-MAAs included porphyra-334, shinorine, palythine and one oxo-MAA, mycosporine-serinol. Porphyra-334, shinorine and palythine belong to the palythine and glycine families considered to be the most common in marine algae [7,9]. The typical MAA of lichens-mycosporine-serinol-was used as a fragmentation model of oxo-MAAs.

The study of the CID30 MS ${ }^{2}$ spectra of the purified MAAs permitted to highlight in Figure 3 their radical fragmentation triggered by the weakening of the ether bond $\mathrm{C}-\mathrm{O}$ and the loss of the methyl radical $(15,023 \mathrm{Da})[26,27]$. 


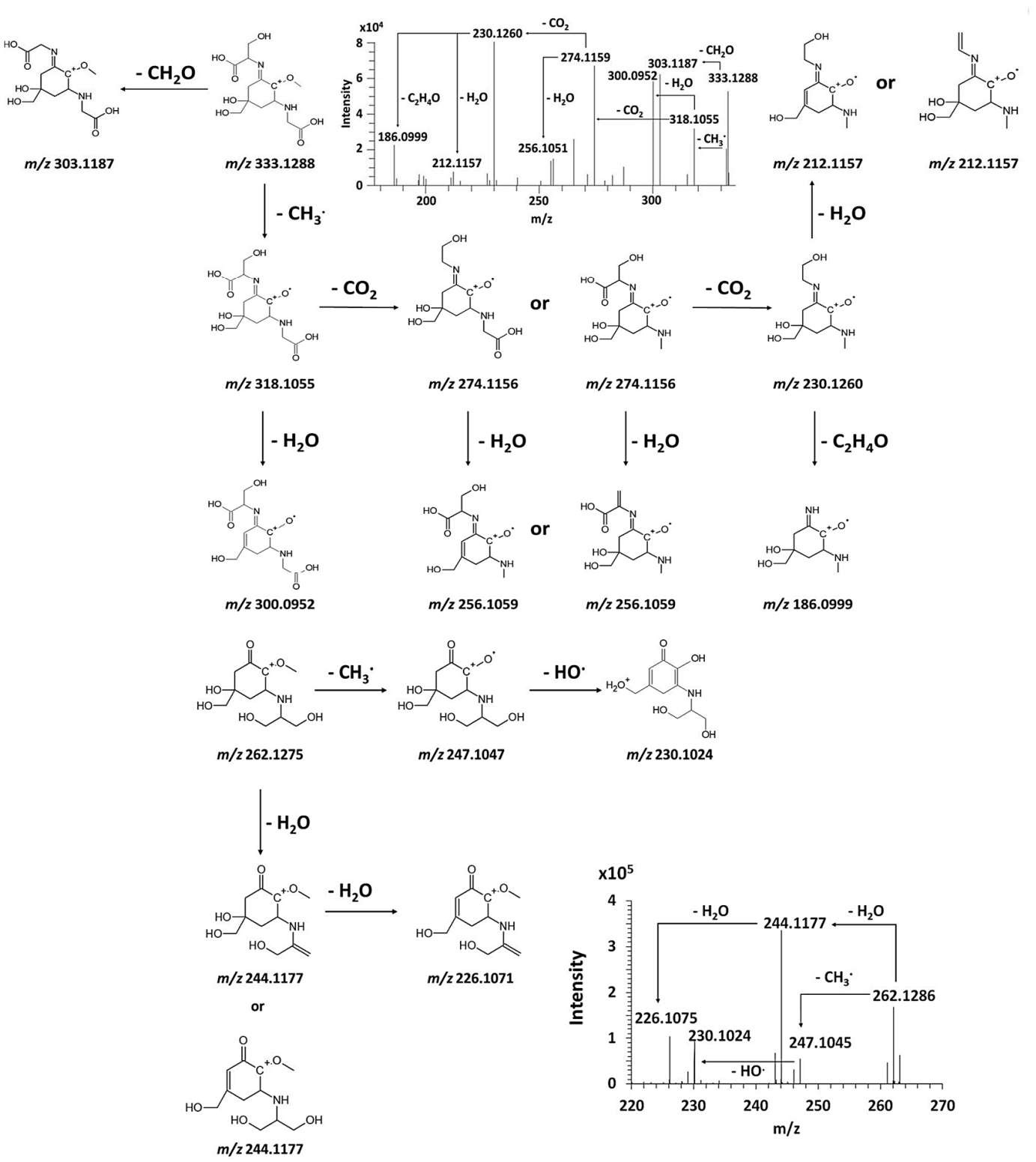

(a)

(b)

Figure 3. Fragmentation pathways of shinorine (a) and mycosporine-serinol (b) from the fragmentation data collection of their CID30MS ${ }^{2}$ spectrum.

Successive decarboxylation or dehydration were mainly observed on the $\left[(\mathrm{M}+\mathrm{H})-\mathrm{CH}_{3}\right]^{+}$. MAA moiety according to the structure of substituents on the $C_{1}$ and $C_{3}[24,26,28]$. The fragmentation of palythine resulted mainly in the loss of water (18.010 Da) and carboxyl (43.989 Da) on the glycine group producing the last most intense fragment ion $\mathrm{m} / \mathrm{z} 186.0999$ (Figure S3a). This fragment ion was also produced after the dealkylation of $m / z 230.1260\left(\mathrm{C}_{2} \mathrm{H}_{4} \mathrm{O}, 44.026 \mathrm{Da}\right)$ and $m / z 244.1417\left(\mathrm{C}_{3} \mathrm{H}_{6} \mathrm{O}\right.$, $58,041 \mathrm{Da}$ ) in CID30 MS² spectra of shinorine (Figure 3a) and porphyra-334 (Figure S3b). Notably, the CID30 MS ${ }^{2}$ spectrum of shinorine and porphyra-334 exhibited a very low intense methyl radical loss and showed highly intense $\left[(\mathrm{M}+\mathrm{H})-\mathrm{CH}_{2} \mathrm{O}\right]^{+}$and $\left[(\mathrm{M}+\mathrm{H})-\mathrm{C}_{2} \mathrm{H}_{4} \mathrm{O}\right]^{+}$moieties instead, corresponding to the same fragment ion $\mathrm{m} / \mathrm{z}$ 303.1187 (Figure 3a and Figure S3b). Indeed, the loss of formaldehyde was observed in prior positive ESI-MS ${ }^{2}$ analysis of shinorine. On the contrary, the monitoring of the fragmentation in $\mathrm{HRMS}^{\mathrm{n}}$ analysis has demonstrated the fragment ion $\mathrm{m} / \mathrm{z} 303.1187$ produced from the porhyra-334 came from a dealkylation $(44.026 \mathrm{Da})$ and not from a decarboxylation $(43.989 \mathrm{Da})$ as it was suggested in prior low-resolution mass spectrometry studies (Figure S3b). As it was demonstrated formerly, the presence of two di-acidic functions in MAA structure could modify the driving force of 
the fragmentation to give priority to decarboxylation $[27,29,30]$. Similarly, the presence of the ketone group and/or the atypical serinol group of the mycosporine-serinol could also give the priority to dehydration in its fragmentation pathway as shows the CID30 MS ${ }^{2}$ spectrum in Figure 3b. Nonetheless, the fragment ion $\mathrm{m} / \mathrm{z} 247.1049$ obtained after the radical methyl loss underwent a rearrangement of its carbon centered radical structure by resonance releasing a hydroxide radical loss and producing the fragment ion $\mathrm{m} / \mathrm{z} 230.1024$. This observation assumed a likely competition between fragmentation pathways starting either with the radical methyl or water loss. Thus, the CID30 MS ${ }^{2}$ spectra of purified MAAs allowed the inventory of the most characteristic neutral and radical losses useful in the monitoring of their different fragmentation pathways and their mining in untargeted analysis.

Although the fragmentation at CID30 permitted to identify the fragment ion $\mathrm{m} / \mathrm{z} 186.0999$ specific of imino-MAAs $[28,30]$, no common fragment ion was detected between imino- and oxo-MAAs. Indeed, low collision energies permitted only to describe the first steps of their radical fragmentation pathway targeting exclusively their substituents. An optimization of the fragmentation conditions at HCD70 allowed to produce, as it is shown in Figure 4 six common fragment ions among the four purified MAAs: $m / z$ 110.0602, $m / z$ 122.0602, $m / z$ 124.0395, $m / z$ 126.0550, 138.0551 and $m / z ~ 140.0707$. Besides, mass spectral data of the three imino-MAAs showed two characteristic high intense fragment ions: $m / z 137.0709$ and $m / z 149.0711$ (Figure 4a-c).
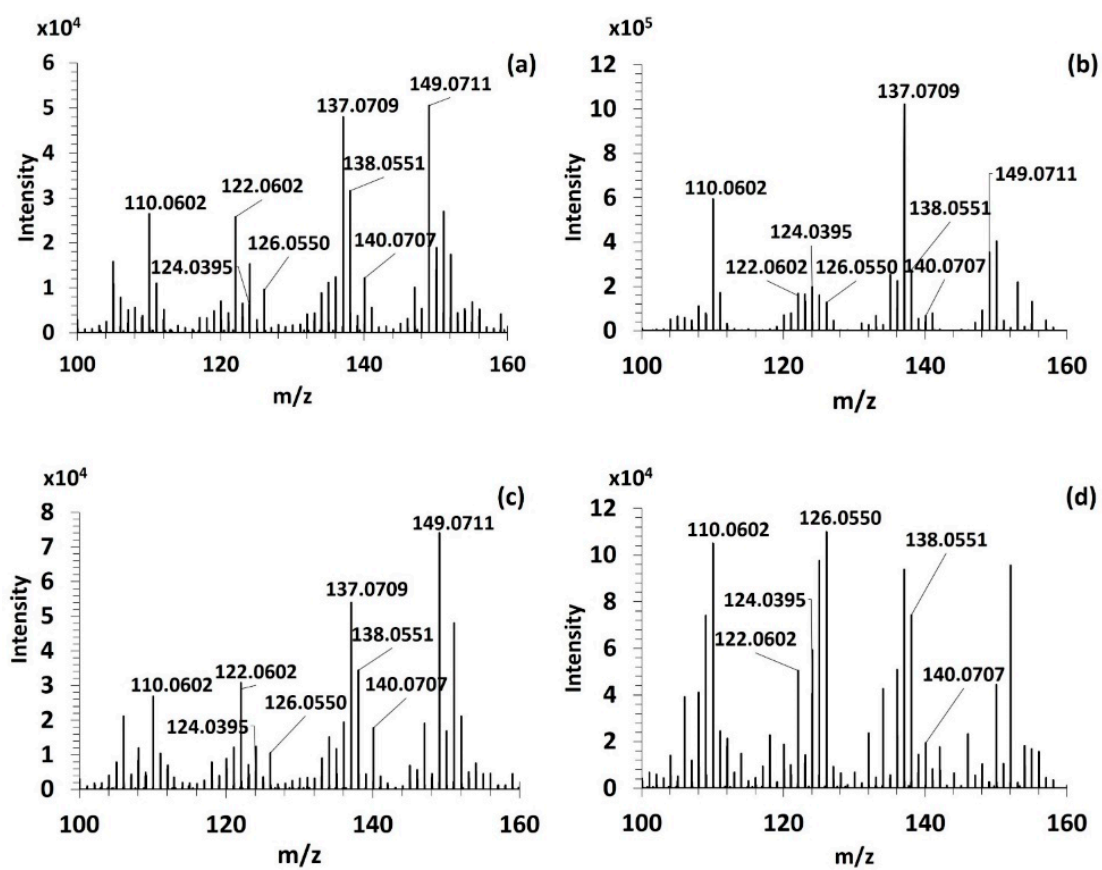

Figure 4. HCD70 $\mathrm{MS}^{2}$ spectrum of shinorine (a), palythine (b), porphyra-334 (c) and mycosporine-serinol (d).

These fragment ions were distributed in the $m / z$ 100-140 range in the spectra of the purified MAAs (Figure 4a-d). The fragment ions found in this mass range lost not only all the substituents but also the ketone or imino-group on the $\mathrm{C}_{1}$ which distinguish oxo- and imino-MAAs. This hypothesis permitted to justify the significative differences observed in the fragment ion distribution above $\mathrm{m} / \mathrm{z} 140$ in the mass spectral data of imino- and oxo-MAAs. An exception was observed for the fragment ions $m / z 137.0709$ and $m / z 149.0711$ in HCD70 MS² only found in imino-MAA spectra (Figure 4a-c). Of note, shinorine and porphyra-334 displayed the same fragmentation tendency due to their similar structure differing only by an additional methyl group on porphyra-334 (Figure 4a,c). Moreover, the fragment ion distribution above $\mathrm{m} / \mathrm{z} 160$ in a HCD70 MS ${ }^{2}$ spectrum of palythine (Figure $4 \mathbf{b}$ ) differed from those observed in spectra of porphyra-334 and shinorine because of the absence of substituent on the $C_{1}$. 
The comparison between different fragmentation conditions revealed that the greatest relative abundance of the six common fragment ions among oxo- and imino-MAAs was achieved at HCD70 as it is shown in Figure 5.

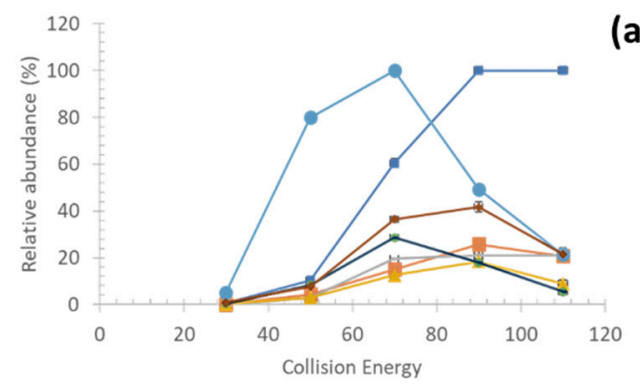

(a)

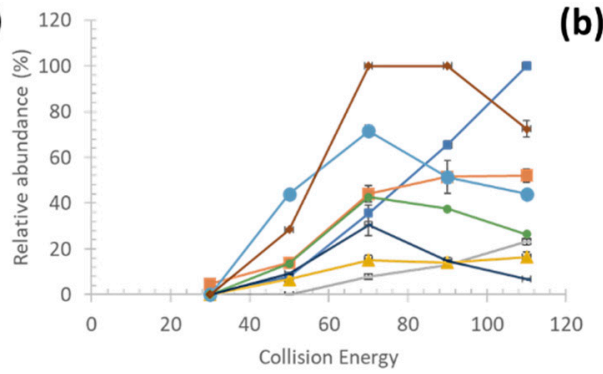

(c)

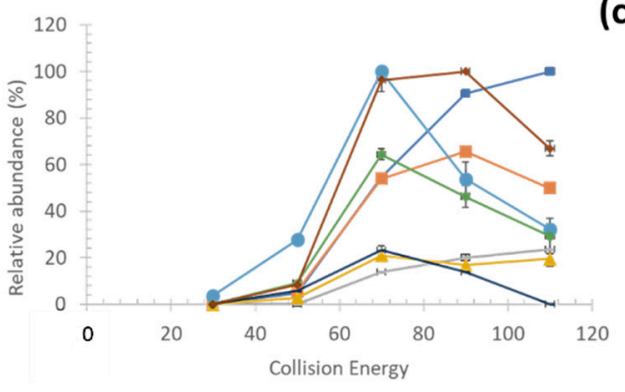

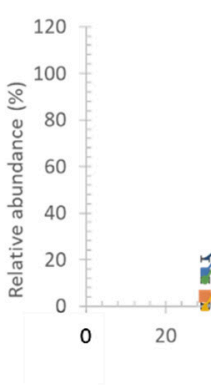

(b)

(d) $\rightarrow-110.0602$

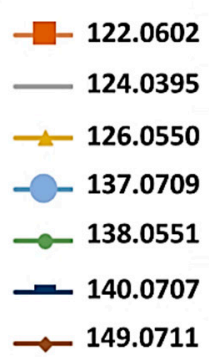

Figure 5. Relative abundance of characteristic fragment ions of MAAs depending on collision energies in $\mathrm{MS}^{2}$ of palythine (a), porphyra-334 (b), shinorine (c) and mycosporine-serinol (d).

The fragment ion $m / z 110.0602$ showed high intensity in all HCD70 MS² spectrum of MAAs (Figure 5a-d) which supposed a common fragmentation route for any MAA regardless of the MAA class. Finally, the fragment ions at $m / z 137.0709$ and $m / z 149.0711$ displayed high intensities in HCD70 $\mathrm{MS}^{2}$ spectra of imino-MAAs (Figure $5 \mathrm{a}-\mathrm{c}$ ), which confirmed their relevance for the distinction between imino- and oxo-candidate-MAAs detected in algal extracts as part of the untargeted analysis.

On the basis of the monitoring of the fragmentation of imino- and oxo-MAAs, a set of eight fragment ions including: $\mathrm{m} / \mathrm{z} 110.0602, \mathrm{~m} / \mathrm{z} 122.0602, \mathrm{~m} / \mathrm{z} 124.0395$ and $\mathrm{m} / \mathrm{z} 126.0550, \mathrm{~m} / \mathrm{z}$ 137.0709, $\mathrm{m} / \mathrm{z} 138.0551, \mathrm{~m} / \mathrm{z} 140.0707$ and $\mathrm{m} / \mathrm{z} 149.0711$ were selected to develop an untargeted screening approach for MAAs in algal extracts.

\subsubsection{Mining and Annotation of MAAs in Algal Model Extract}

An untargeted ddMS $2 / \mathrm{MS}^{3}$ analysis was carried out using the set of eight fragment ions, neutral and radical losses defined above to screen for candidate-MAAs in the model algae Gymnogongrus devoniensis.

Data-processing using the untargeted workflow designed using Compound Discoverer ${ }^{\mathrm{TM}}$ software to mine and flag candidate-MAAs retrieved 1498 candidate compounds. The detection of MAAs was considered positive when the intensity of precursor ions exceeded the $1 \times 10^{4}$ threshold and when a minimal number of five fragment ions out of eight could be observed in their HCD70 MS ${ }^{2}$ OT scans. These criteria of result selection reduced the number of candidate-MAAs to 41 as reported in Table 3 . 
Table 3. Candidate-MAAs detected in the model algae Gymnogongrus devoniensis using the Fragment Ion Search (FISh).

\begin{tabular}{|c|c|c|c|c|c|c|c|}
\hline MAAs & $\begin{array}{c}\text { In Source } \\
\text { Fragmentation }\end{array}$ & Formula & Monoisotopic Mass (Da) & {$[\mathrm{M}+\mathrm{H}]+(m / z)$} & Area $\operatorname{Max}\left(10^{5}\right)$ & RT [min] & $\begin{array}{c}\text { Number of } \\
\text { Fragment Ions (/8) }\end{array}$ \\
\hline Porphyra-334 & - & $\mathrm{C}_{14} \mathrm{H}_{22} \mathrm{O}_{8} \mathrm{~N}_{2}$ & 346.1372 & 347.1444 & 693 & 10.14 & 8 \\
\hline Unknown & - & $\mathrm{C}_{14} \mathrm{H}_{28} \mathrm{O}_{3} \mathrm{~N}_{2}$ & 272.2099 & 273.2170 & 0.15 & 8.86 & 8 \\
\hline Unknown & - & $\mathrm{C}_{10} \mathrm{H}_{17} \mathrm{O}_{6} \mathrm{~N}$ & 247.1053 & 248.1126 & 0.18 & 11.03 & 8 \\
\hline Unknown & 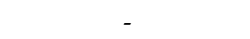 & $\mathrm{C}_{10} \mathrm{H}_{19} \mathrm{O}_{4} \mathrm{~N}_{3}$ & 245.1374 & 246.1447 & 0.19 & 10.93 & 8 \\
\hline Asterina-330 & {$\left[(\mathrm{M}+\mathrm{H})-\left(\mathrm{CH}_{3} ; \mathrm{CO}_{2}\right)\right]$} & $\mathrm{C}_{10} \mathrm{H}_{17} \mathrm{O}_{4} \mathrm{~N}_{2}$ & 229.1187 & 230.1259 & 0.59 & 11.02 & 8 \\
\hline Asterina-330 & {$\left[(\mathrm{M}+\mathrm{H})-\mathrm{CH}_{3}\right]$} & $\mathrm{C}_{11} \mathrm{H}_{17} \mathrm{O}_{6} \mathrm{~N}_{2}$ & 273.1084 & 274.1157 & 1.23 & 11.03 & 8 \\
\hline Unknown & - & $\mathrm{C}_{14} \mathrm{H}_{22} \mathrm{O}_{9} \mathrm{~N}_{2}$ & 362.1320 & 363.1389 & 1.25 & 10.84 & 8 \\
\hline Palythine & {$\left[(\mathrm{M}+\mathrm{H})-\left(\mathrm{CH}_{3} ; \mathrm{CO}_{2}\right)\right]$} & $\mathrm{C}_{8} \mathrm{H}_{13} \mathrm{O}_{3} \mathrm{~N}_{2}$ & 185.0924 & 186.0999 & 1.02 & 11.15 & 8 \\
\hline Unknown & (13) - & $\mathrm{C}_{12} \mathrm{H}_{19} \mathrm{O}_{3} \mathrm{~N}_{3} \mathrm{~S}$ & 285.1142 & 286.1215 & 0.10 & 8.11 & 8 \\
\hline Aplysiapalythine-B & - & $\mathrm{C}_{12} \mathrm{H}_{20} \mathrm{O}_{5} \mathrm{~N}_{2}$ & 272.1367 & 273.1436 & 76.5 & 9.00 & 8 \\
\hline Shinorine & - & $\mathrm{C}_{13} \mathrm{H}_{20} \mathrm{O}_{8} \mathrm{~N}_{2}$ & 332.1214 & 333.1292 & 85.2 & 10.52 & 8 \\
\hline Palythinol & - & $\mathrm{C}_{13} \mathrm{H}_{22} \mathrm{O}_{6} \mathrm{~N}_{2}$ & 302.1475 & 303.1551 & 11.3 & 10.20 & 8 \\
\hline Mycosporine-2-glycine & - & $\mathrm{C}_{12} \mathrm{H}_{18} \mathrm{O}_{7} \mathrm{~N}_{2}$ & 302.1112 & 303.1185 & 3.55 & 10.15 & 8 \\
\hline Palythine & - & $\mathrm{C}_{10} \mathrm{H}_{16} \mathrm{O}_{5} \mathrm{~N}_{2}$ & 244.1051 & 245.1124 & 122 & 11.14 & 8 \\
\hline Unknown & - & $\mathrm{C}_{15} \mathrm{H}_{24} \mathrm{O}_{10} \mathrm{~N}_{2} \mathrm{~S}$ & 424.1146 & 425.1218 & 4.73 & 10.16 & 8 \\
\hline Mycosporine methyl-amine threonine & - & $\mathrm{C}_{13} \mathrm{H}_{22} \mathrm{O}_{6} \mathrm{~N}_{2}$ & 302.1475 & 303.1551 & 2.43 & 8.48 & 8 \\
\hline Asterina-330 & - & $\mathrm{C}_{12} \mathrm{H}_{20} \mathrm{O}_{6} \mathrm{~N}_{2}$ & 288.1316 & 289.1394 & 187 & 11.03 & 8 \\
\hline Palythene/Usujirene & - & $\mathrm{C}_{13} \mathrm{H}_{20} \mathrm{O}_{5} \mathrm{~N}_{2}$ & 284.1368 & 285.1445 & 137 & 7.81 & 8 \\
\hline Palythene/Usujirene & {$\left[(\mathrm{M}+\mathrm{H})-\left(\mathrm{CH}_{3} ; \mathrm{CO}_{2}\right)\right]$} & $\mathrm{C}_{11} \mathrm{H}_{17} \mathrm{O}_{3} \mathrm{~N}_{2}$ & 225.1237 & 226.1311 & 0.39 & 7.81 & 7 \\
\hline Unknown & - & $\mathrm{C}_{13} \mathrm{H}_{22} \mathrm{O}_{7} \mathrm{~N}_{2}$ & 318.1425 & 319.1493 & 1.63 & 10.17 & 7 \\
\hline Unknown & - & $\mathrm{C}_{13} \mathrm{H}_{20} \mathrm{O}_{6} \mathrm{~N}_{2}$ & 300.1320 & 301.1392 & 1.99 & 10.15 & 7 \\
\hline Unknown & - & $\mathrm{C}_{11} \mathrm{H}_{18} \mathrm{O}_{7} \mathrm{~N}_{2} \mathrm{~S}$ & 322.0827 & 323.0899 & 0.58 & 11.15 & 7 \\
\hline Unknown & - & $\mathrm{C}_{11} \mathrm{H}_{18} \mathrm{O}_{5} \mathrm{~N}_{2}$ & 258.1217 & 259.1289 & 1.07 & 10.05 & 7 \\
\hline Mycosporine-glycine-valine & - & $\mathrm{C}_{15} \mathrm{H}_{24} \mathrm{O}_{7} \mathrm{~N}_{2}$ & 344.1579 & 345.1652 & 1.20 & 9.01 & 7 \\
\hline Unknown & - & $\mathrm{C}_{14} \mathrm{H}_{22} \mathrm{O}_{7} \mathrm{~N}_{2}$ & 330.1420 & 331.1491 & 1.07 & 9.43 & 7 \\
\hline Palythine glutamic-acid & - & $\mathrm{C}_{13} \mathrm{H}_{20} \mathrm{O}_{7} \mathrm{~N}_{2}$ & 316.1266 & 317.1338 & 6.26 & 9.86 & 7 \\
\hline Unknown & - & $\mathrm{C}_{20} \mathrm{H}_{30} \mathrm{O}_{10} \mathrm{~N}_{2}$ & 458.1903 & 459.1975 & 2.77 & 10.04 & 6 \\
\hline Unknown & - & $\mathrm{C}_{13} \mathrm{H}_{22} \mathrm{O}_{8} \mathrm{~N}_{2} \mathrm{~S}$ & 366.1092 & 367.1164 & 0.49 & 11.02 & 6 \\
\hline Palythine-serine & - & $\mathrm{C}_{11} \mathbf{H}_{18} \mathrm{O}_{6} \mathbf{N}_{2}$ & 274.1158 & 275.1231 & 0.47 & 11.54 & 6 \\
\hline Unknown & - & $\mathrm{C}_{16} \mathrm{H}_{26} \mathrm{O}_{8} \mathrm{~N}_{4}$ & 402.1751 & 403.1816 & 0.44 & 10.69 & 6 \\
\hline Unknown & - & $\mathrm{C}_{15} \mathrm{H}_{24} \mathrm{O}_{8} \mathrm{~N}_{2}$ & 360.1522 & 361.1602 & 0.28 & 9.52 & 6 \\
\hline Unknown & - & $\mathrm{C}_{13} \mathrm{H}_{23} \mathrm{O}_{6} \mathrm{~N}_{5}$ & 345.1647 & 346.1722 & 0.22 & 11.91 & 5 \\
\hline Unknown & - & $\mathrm{C}_{15} \mathrm{H}_{24} \mathrm{O}_{8} \mathrm{~N}_{2}$ & 360.1522 & 361.1598 & 0.21 & 9.96 & 5 \\
\hline Unknown & - & $\mathrm{C}_{13} \mathrm{H}_{22} \mathrm{O}_{5} \mathrm{~N}_{2}$ & 286.1525 & 287.1240 & 0.17 & 8.05 & 5 \\
\hline Unknown & - & $\mathrm{C}_{15} \mathrm{H}_{23} \mathrm{O}_{8} \mathrm{~N}_{3}$ & 373.1484 & 374.1557 & 0.53 & 10.50 & 5 \\
\hline Unknown & - & $\mathrm{C}_{18} \mathrm{H}_{22} \mathrm{O}_{8} \mathrm{~N}_{2}$ & 394.1369 & 395.1441 & 0.46 & 8.28 & 5 \\
\hline Unknown & - & $\mathrm{C}_{14} \mathrm{H}_{22} \mathrm{O}_{10} \mathrm{~N}_{2} \mathrm{~S}$ & 410.0990 & 411.1060 & 0.50 & 10.53 & 5 \\
\hline Unknown & - & $\mathrm{C}_{13} \mathrm{H}_{20} \mathrm{O}_{6} \mathrm{~N}_{2}$ & 300.1320 & 301.1392 & 2.66 & 9.28 & 5 \\
\hline Aplysiapalythine-A & - & $\mathrm{C}_{13} \mathrm{H}_{22} \mathrm{O}_{6} \mathrm{~N}_{2}$ & 302.1475 & 303.1551 & 2.07 & 9.72 & 5 \\
\hline Unknown & - & $\mathrm{C}_{14} \mathrm{H}_{22} \mathrm{O}_{7} \mathrm{~N}_{2} \mathrm{~S}$ & 362.1143 & 363.1215 & 0.28 & 7.81 & 5 \\
\hline Mycosporine-glycine & - & $\mathrm{C}_{10} \mathrm{H}_{15} \mathrm{O}_{6} \mathrm{~N}$ & 245.0899 & 246.0972 & 0.93 & 8.56 & 5 \\
\hline
\end{tabular}

The known MAAs were emphasized in bold. MAAs subject to ion source fragmentation were indicated by the moiety [(M+H)-neutral and/or radical loss ${ }^{+}$generated. 
All the 41 exact masses were listed in the final result table according to the number of fragment ions detected in their HCD70 MS² OT scans. Of note, 14 of them were identified in the literature [26].

The annotation of candidate-MAA was also carried out with the detection of characteristic neutral and radical losses. Indeed, a CID30 ddMS ${ }^{3}$ IT scan was triggered after the detection of neutral and radical losses in prior CID30 ddMS ${ }^{2}$ OT scan of every putative MAAs. Mechanisms of decarboxylation and dehydration were observed on the $\left[(\mathrm{M}+\mathrm{H})-\mathrm{CH}_{3}\right]^{+}$. moiety in the putative MAA spectra as it was detailed in Figure S4. These observations proved the tracking of neutral and radical losses was all the more relevant since the fragmentation pathways of MAAs permitted the production of the eight characteristic fragment ions observed in ddMS ${ }^{2}$ HCD70 OT spectra. In this way, any detected mass showing a CID30 ddMS ${ }^{3}$ IT scan in addition to a HCD70 ddMS ${ }^{2}$ OT scan with at least five annotated fragment ions was a putative MAA.

Surprisingly, four exact masses in Table 3 coeluted with the identified MAAs palythene/usujirene $(225,1237 \mathrm{Da})$, asterina-330 (229,1187 Da; 273,1084 Da) and palythine (185,0924 Da). The detected mass 185.0924 Da corresponded to the fragment ion $\mathrm{m} / \mathrm{z} 186.099$ which gave origin to all the fragment ions characteristic of imino-MAAs. Likewise, the detected masses 229.1187 Da and 273.1084 Da have been already reported in the literature as typical fragment ions in the fragmentation pathways of asterina-330 [28]. These observations indicated in-source fragmentation of palythene/usujirene, asterina-330 and palythine. Moreover, they confirmed the capability of the method developed to retrieve coeluted MAAs.

In summary, the untargeted screening approach permitted to flag successfully 23 novel candidate-MAAs in Gymnogongrus devoniensis in addition to the 14 known ones. Besides, these findings corroborated the hypothesis that this red alga contained a high diversity in MAAs characteristic of algae belonging to the Bangiales order [21].

\subsection{Method Validation by Targeted Analysis}

To validate the developed untargeted screening method, a targeted analysis based on a Top3 $\mathrm{MS}^{2}$ acquisition was carried out on the model algal extract Gymnogongrus devoniensis. The workflow designed for the targeted screening of MAAs illustrated in Figure S1.

All the detected compounds were searched for in the in-house database of over 41 reported MAAs. At the outcome of the targeted screening analysis, 14 compounds were detected and identified on Table 4.

All the exact masses were detected with 3 ppm mass accuracy. The FISh score showed at least $50 \%$ of experimental fragment ions detected in spectra of 9 MAAs matched with those found in silico. The stepped collision-energy mode was applied to collect and compile mass spectral data both in HCD30 and HCD70 permitting thus the detection of the set of eight fragment ions, neutral and radical losses chosen in untargeted analysis. Fragmentation at HCD30 allowed the production of intense fragment ions showing the first fragmentation steps of MAAs involving demethylation, decarboxylation and dehydration (Table 4, See also Figure S5). Only the mycosporine-glycine did not display the fragment ions $\mathrm{m} / \mathrm{z} 137.0709$ and $\mathrm{m} / \mathrm{z} 149.0711$ confirming its affiliation to the oxo-MAAs. Similarly, the fragmentation permitted to make the distinction between the palythine-glutamic acid newly characterized by Orfanoudaki et al. [16] and its oxo-isomer mycosporine-glutamine in the algal sample. Hence, the choice of the fragment ion set to mine candidate-MAAs allowed a satisfactory coverage of their structural diversity.

In conclusion, the targeted analysis of Gymnogongrus devoniensis permitted to validate the developed untargeted ddMS ${ }^{2} / \mathrm{MS}^{3}$ analysis and confirm its efficiency to cover the MAA present in a sample. 
Table 4. Targeted analysis of the model algal sample Gymnogongrus devoniensis. FISh coverage indicates the percentage of experimental fragment ions matching with those obtained in silico fragmentation. The number of fragment ions included in the set used in untargeted analysis of MAAs is also referred. * Please note that mycosporine-glycine was the only compound for which the fragment ions $\mathrm{m} / \mathrm{z} 137.0709$ and $m / z 149.0711$ were not detected in ddMS ${ }^{2}$ spectrum.

\begin{tabular}{|c|c|c|c|c|c|}
\hline MAAs & {$[\mathrm{M}+\mathrm{H}]^{+}$} & $\begin{array}{l}\text { Retention Time } \\
\text { (min) }\end{array}$ & $\begin{array}{c}\text { FISh Coverage } \\
(\%)\end{array}$ & $\begin{array}{c}\text { Number of } \\
\text { Characteristic } \\
\text { Fragment Ions of } \\
\text { MAAs (/8) }\end{array}$ & $\begin{array}{c}\text { Neutral and } \\
\text { Radical Losses }\end{array}$ \\
\hline Palythine & 245.1123 & 11.14 & 42 & 8 & $\mathrm{CH}_{3} ; \mathrm{CO}_{2} ; \mathrm{H}_{2} \mathrm{O}$ \\
\hline Mycosporine-glycine * & 246.0971 & 8.56 & 69 & 5 & $\mathrm{CH}_{3} ; \mathrm{CO}_{2} ; \mathrm{H}_{2} \mathrm{O}$ \\
\hline Aplysiapalythine B & 273.1436 & 9.01 & 52 & 8 & $\mathrm{CH}_{3} ; \mathrm{CO}_{2} ; \mathrm{H}_{2} \mathrm{O}$ \\
\hline Palythine-serine & 275.1234 & 11.54 & 67 & 5 & $\mathrm{CH}_{3} ; \mathrm{CO}_{2} ; \mathrm{H}_{2} \mathrm{O}$ \\
\hline Palythene/Usujirene & 285.1440 & 7.81 & 48 & 8 & $\mathrm{CH}_{3} ; \mathrm{CO}_{2} ; \mathrm{H}_{2} \mathrm{O}$ \\
\hline Asterina-330 & 289.1389 & 11.03 & 59 & 8 & $\begin{array}{l}\mathrm{CH}_{3} ; \mathrm{CO}_{2} ; \mathrm{H}_{2} \mathrm{O} \\
\mathrm{CH}_{3} \mathrm{O} ; \mathrm{C}_{2} \mathrm{H}_{4} \mathrm{O}\end{array}$ \\
\hline Mycosporine-2-glycine & 303.1185 & 10.15 & 50 & 8 & $\mathrm{CH}_{3} ; \mathrm{CO}_{2} ; \mathrm{H}_{2} \mathrm{O}$ \\
\hline Aplysiapalythine A & 303.1542 & 9.72 & 38 & 4 & $\mathrm{CH}_{3} ; \mathrm{CO}_{2} ; \mathrm{H}_{2} \mathrm{O}$ \\
\hline Palythinol & 303.1548 & 10.20 & 57 & 8 & $\mathrm{CH}_{3} ; \mathrm{CO}_{2} ; \mathrm{H}_{2} \mathrm{O}$ \\
\hline $\begin{array}{l}\text { Mycosporine-methyl } \\
\text { amine threonine }\end{array}$ & 303.1549 & 8.48 & 64 & 8 & $\mathrm{CH}_{3} ; \mathrm{CO}_{2} ; \mathrm{H}_{2} \mathrm{O}$ \\
\hline Palythine-glutamic acid & 317.1338 & 9.86 & 45 & 8 & $\mathrm{CH}_{3} ; \mathrm{CO}_{2} ; \mathrm{H}_{2} \mathrm{O}$ \\
\hline Shinorine & 333.1286 & 10.52 & 48 & 8 & $\begin{array}{l}\mathrm{CH}_{3} ; \mathrm{CO}_{2} ; \mathrm{H}_{2} \mathrm{O} ; \\
\mathrm{CH}_{2} \mathrm{O} ; \mathrm{C}_{2} \mathrm{H}_{4} \mathrm{O}\end{array}$ \\
\hline Mycosporine-glycine-valine & 345.1653 & 9.03 & 63 & 7 & $\mathrm{CH}_{3} ; \mathrm{CO}_{2} ; \mathrm{H}_{2} \mathrm{O}$ \\
\hline Porphyra-334 & 347.1444 & 10.14 & 67 & 8 & $\begin{array}{l}\mathrm{CH}_{3} ; \mathrm{CO}_{2} ; \mathrm{H}_{2} \mathrm{O} ; \\
\mathrm{C}_{2} \mathrm{H}_{4} \mathrm{O} ; \mathrm{C}_{3} \mathrm{H}_{6} \mathrm{O}\end{array}$ \\
\hline
\end{tabular}

\subsection{Discovery of Novel MAAs}

Fractions resulted from the HILIC fractionation of the extract of Gymnogongrus devoniensis were collected on-line in order to elucidate, or confirm by multistage fragmentation, the structures of seven candidate-MAAs detected in untargeted analysis.

As it is shown in Table 5, the study of the ion precursors and their most intense fragment ions in multistage fragmentation permitted to complete the fragmentation data obtained in untargeted analysis. 
Table 5. Structural elucidation of novel MAAs. Fragment ions detected in $\mathrm{MS}^{2}$, $\mathrm{MS}^{3}$ and $\mathrm{MS}^{4}$ fragmentation were reported for the seven masses annotated from A-G.

\begin{tabular}{|c|c|c|c|c|c|}
\hline \multirow{2}{*}{ Compound } & \multirow{2}{*}[\mathbf{M}+\mathrm{H}]{$^{+}(m / z)$} & \multirow{2}{*}{ Formula $[\mathrm{M}+\mathrm{H}]^{+}$} & \multicolumn{3}{|c|}{ Fragment Ions $(m / z)$} \\
\hline & & & MS $^{2}$ & MS $^{3}$ & MS $^{4}$ \\
\hline A & 301.1393 & $\mathrm{C}_{13} \mathrm{H}_{21} \mathrm{O}_{6} \mathrm{~N}_{2}$ & $\begin{array}{c}286.1158 \mathrm{C}_{12} \mathrm{H}_{18} \mathrm{O}_{6} \mathrm{~N}_{2}(-2.11 \mathrm{ppm}) \\
283.1279 \mathrm{C}_{13} \mathrm{H}_{19} \mathrm{O}_{5} \mathrm{~N}_{2}(-3.13 \mathrm{ppm}) \\
\text { 257.1152 } \mathrm{C}_{11} \mathrm{H}_{17} \mathrm{O}_{5} \mathrm{~N}_{2}(-2.9 \mathrm{ppm}) \\
243.0974 \mathrm{C}_{10} \mathrm{H}_{15} \mathrm{O}_{5} \mathrm{~N}_{2}(-3.4 \mathrm{ppm}) \\
242.1260 \mathrm{C}_{11} \mathrm{H}_{18} \mathrm{O}_{4} \mathrm{~N}_{2}(-2.67 \mathrm{ppm}) \\
225.0865 \mathrm{C}_{10} \mathrm{H}_{13} \mathrm{O}_{4} \mathrm{~N}_{2}(-4.63 \mathrm{ppm}) \\
211.1078 \mathrm{C}_{10} \mathrm{H}_{15} \mathrm{O}_{3} \mathrm{~N}_{2}(-1.08 \mathrm{ppm}) \\
\text { 199.1077 } \mathrm{C}_{9} \mathrm{H}_{15} \mathrm{O}_{3} \mathrm{~N}_{2}(-0.54 \mathrm{ppm})\end{array}$ & $\begin{array}{l}265.1186 \mathrm{C}_{13} \mathrm{H}_{17} \mathrm{O}_{4} \mathrm{~N}_{2}(-1.52 \mathrm{ppm}) \\
239.1482 \mathrm{C}_{12} \mathrm{H}_{19} \mathrm{O}_{3} \mathrm{~N}_{2}(-0.63 \mathrm{ppm}) \\
221.1377 \mathrm{C}_{12} \mathrm{H}_{17} \mathrm{O}_{2} \mathrm{~N}_{2}(-0.29 \mathrm{ppm})\end{array}$ & \\
\hline B & 319.1495 & $\mathrm{C}_{13} \mathrm{H}_{23} \mathrm{O}_{7} \mathrm{~N}_{2}$ & $\begin{array}{c}304.1265 \mathrm{C}_{12} \mathrm{H}_{20} \mathrm{O}_{7} \mathrm{~N}_{2}(1.88 \mathrm{ppm}) \\
301.1392 \mathrm{C}_{13} \mathrm{H}_{21} \mathrm{O}_{6} \mathrm{~N}_{2}(-2.46 \mathrm{ppm}) \\
289.1394 \mathrm{C}_{12} \mathrm{H}_{21} \mathrm{O}_{6} \mathrm{~N}_{2}(-2.46 \mathrm{ppm}) \\
275.1237 \mathrm{C}_{11} \mathrm{H}_{19} \mathrm{O}_{6} \mathrm{~N}_{2}(-2.15 \mathrm{ppm}) \\
245.1132 \mathrm{C}_{10} \mathrm{H}_{17} \mathrm{O}_{5} \mathrm{~N}_{2}(-2.60 \mathrm{ppm})\end{array}$ & 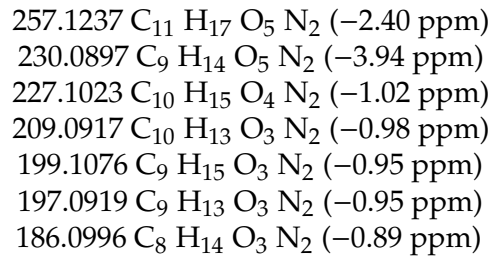 & \\
\hline C & 331.1499 & $\mathrm{C}_{14} \mathrm{H}_{23} \mathrm{O}_{7} \mathrm{~N}_{2}$ & $\begin{array}{c}\text { 316.1264 } \mathrm{C}_{13} \mathrm{H}_{20} \mathrm{O}_{7} \mathrm{~N}_{2}(-1.96 \mathrm{ppm}) \\
\text { 313.1393 } \mathrm{C}_{14} \mathrm{H}_{21} \mathrm{O}_{6} \mathrm{~N}_{2}(-0.71 \mathrm{ppm}) \\
\text { 301.1035 } \mathrm{C}_{12} \mathrm{H}_{17} \mathrm{O}_{7} \mathrm{~N}_{2}(-0.09 \mathrm{ppm}) \\
\text { 295.1289 } \mathrm{C}_{14} \mathrm{H}_{19} \mathrm{O}_{5} \mathrm{~N}_{2}(-0.74 \mathrm{ppm}) \\
\text { 272.1367 } \mathrm{C}_{12} \mathrm{H}_{20} \mathrm{O}_{5} \mathrm{~N}_{2}(-2.17 \mathrm{ppm}) \\
\text { 241.1182 } \mathrm{C}_{11} \mathrm{H}_{17} \mathrm{O}_{4} \mathrm{~N}_{2}(-0.64 \mathrm{ppm}) \\
228.1468 \mathrm{C}_{11} \mathrm{H}_{20} \mathrm{O}_{3} \mathrm{~N}_{2}(-2.64 \mathrm{ppm}) \\
213.1234 \mathrm{C}_{10} \mathrm{H}_{17} \mathrm{O}_{3} \mathrm{~N}_{2}(-1.73 \mathrm{ppm}) \\
\text { 197.1286 } \mathrm{C}_{10} \mathrm{H}_{17} \mathrm{O}_{2} \mathrm{~N}_{2}(-0.4 \mathrm{ppm}) \\
\text { 346.1361 } \mathrm{C}_{14} \mathrm{H}_{22} \mathrm{O}_{8} \mathrm{~N}_{2}(-4.35 \mathrm{ppm}) \\
317.1346 \mathrm{C}_{13} \mathrm{H}_{21} \mathrm{O}_{7} \mathrm{~N}_{2}(-0.27 \mathrm{ppm}) \\
315.1192 \mathrm{C}_{13} \mathrm{H}_{19} \mathrm{O}_{7} \mathrm{~N}_{2}(0.01 \mathrm{ppm}) \\
302.1472 \mathrm{C}_{13} \mathrm{H}_{22} \mathrm{O}_{6} \mathrm{~N}_{2}(-1.97 \mathrm{ppm}) \\
271.1288 \mathrm{C}_{12} \mathrm{H}_{19} \mathrm{O}_{5} \mathrm{~N}_{2}(-0.54 \mathrm{ppm}) \\
258.1574 \mathrm{C}_{12} \mathrm{H}_{22} \mathrm{O}_{4} \mathrm{~N}_{2}(-2.04 \mathrm{ppm}) \\
227.1388 \mathrm{C}_{11} \mathrm{H}_{19} \mathrm{O}_{3} \mathrm{~N}_{2}(-3.72 \mathrm{ppm})\end{array}$ & & \\
\hline
\end{tabular}


Table 5. Cont.

\begin{tabular}{|c|c|c|c|c|c|}
\hline \multirow{2}{*}{ Compound } & \multirow{2}{*}[\mathbf{M}+\mathbf{H}]{$^{+}(m / z)$} & \multirow{2}{*}{ Formula $[\mathrm{M}+\mathrm{H}]^{+}$} & \multicolumn{3}{|c|}{ Fragment Ions $(m / z)$} \\
\hline & & & MS $^{2}$ & MS $^{3}$ & MS $^{4}$ \\
\hline $\mathrm{E}$ & 363.1398 & $\mathrm{C}_{14} \mathrm{H}_{23} \mathrm{O}_{9} \mathrm{~N}_{2}$ & $\begin{array}{c}348.1166 \mathrm{C}_{13} \mathrm{H}_{20} \mathrm{O}_{9} \mathrm{~N}_{2}(-0.8 \mathrm{ppm}) \\
345.1292 \mathrm{C}_{14} \mathrm{H}_{21} \mathrm{O}_{8} \mathrm{~N}_{2}(-1.68 \mathrm{ppm}) \\
330.1161 \mathrm{C}_{13} \mathrm{H}_{18} \mathrm{O}_{8} \mathrm{~N}_{2}(-0.62 \mathrm{ppm}) \\
319.1134 \mathrm{C}_{12} \mathrm{H}_{19} \mathrm{O}_{8} \mathrm{~N}_{2}(-2.04 \mathrm{ppm}) \\
304.1263 \mathrm{C}_{12} \mathrm{H}_{20} \mathrm{O}_{7} \mathrm{~N}_{2}(-2.6 \mathrm{ppm}) \\
286.1160 \mathrm{C}_{12} \mathrm{H}_{18} \mathrm{O}_{6} \mathrm{~N}_{2}(-1.8 \mathrm{ppm}) \\
283.0923 \mathrm{C}_{12} \mathrm{H}_{15} \mathrm{O}_{6} \mathrm{~N}_{2}(-2.9 \mathrm{ppm}) \\
239.1022 \mathrm{C}_{11} \mathrm{H}_{15} \mathrm{O}_{4} \mathrm{~N}_{2}(-4.27 \mathrm{ppm})\end{array}$ & $\begin{array}{l}309.1081 \mathrm{C}_{14} \mathrm{H}_{17} \mathrm{O}_{6} \mathrm{~N}_{2}(-1.39 \mathrm{ppm}) \\
301.1029 \mathrm{C}_{12} \mathrm{H}_{17} \mathrm{O}_{7} \mathrm{~N}_{2}(-0.76 \mathrm{ppm})\end{array}$ & \\
\hline $\mathrm{F}$ & 367.1169 & $\mathrm{C}_{13} \mathrm{H}_{23} \mathrm{O}_{8} \mathrm{~N}_{2} \mathrm{~S}$ & $\begin{array}{c}352.0928 \mathrm{C}_{12} \mathrm{H}_{20} \mathrm{O}_{8} \mathrm{~N}_{2} \mathrm{~S}(-2.38 \mathrm{ppm}) \\
349.1851 \mathrm{C}_{13} \mathrm{H}_{21} \mathrm{O}_{7} \mathrm{~N}_{2} \mathrm{~S} \\
323.1699 \mathrm{C}_{12} \mathrm{H}_{23} \mathrm{O}_{6} \mathrm{~N}_{2} \mathrm{~S} \\
321.0742 \mathrm{C}_{11} \mathrm{H}_{17} \mathrm{O}_{7} \mathrm{~N}_{2} \mathrm{~S} \\
308.0671 \mathrm{C}_{10} \mathrm{H}_{16} \mathrm{O}_{7} \mathrm{~N}_{2} \mathrm{~S}(-2.5 \mathrm{ppm})\end{array}$ & $\begin{array}{l}334.0822 \mathrm{C}_{12} \mathrm{H}_{18} \mathrm{O}_{7} \mathrm{~N}_{2} \mathrm{~S} \\
331.1648 \mathrm{C}_{13} \mathrm{H}_{19} \mathrm{O}_{6} \mathrm{~N}_{2} \mathrm{~S} \\
305.1586 \mathrm{C}_{11} \mathrm{H}_{17} \mathrm{O}_{6} \mathrm{~N}_{2} \mathrm{~S} \\
303.1796 \mathrm{C}_{11} \mathrm{H}_{15} \mathrm{O}_{6} \mathrm{~N}_{2} \mathrm{~S} \\
287.1890 \mathrm{C}_{12} \mathrm{H}_{19} \mathrm{O}_{4} \mathrm{~N}_{2} \mathrm{~S}\end{array}$ & $\begin{array}{l}290.093 \mathrm{C}_{11} \mathrm{H}_{18} \mathrm{O}_{5} \mathrm{~N}_{2} \mathrm{~S} \\
\quad(-2.7 \mathrm{ppm}) \\
277.0484 \mathrm{C}_{9} \mathrm{H}_{13} \mathrm{O}_{6} \mathrm{~N}_{2} \mathrm{~S} \\
228.1101 \mathrm{C}_{11} \mathrm{H}_{20} \mathrm{O}_{3} \mathrm{~N}_{2}\end{array}$ \\
\hline G & 411.1063 & $\mathrm{C}_{14} \mathrm{H}_{23} \mathrm{O}_{10} \mathrm{~N}_{2} \mathrm{~S}$ & $\begin{array}{c}396.083 \mathrm{C}_{13} \mathrm{H}_{20} \mathrm{O}_{10} \mathrm{~N}_{2} \mathrm{~S}(-1.48 \mathrm{ppm}) \\
393.096 \mathrm{C}_{14} \mathrm{H}_{21} \mathrm{O}_{9} \mathrm{~N}_{2} \mathrm{~S}(-1.64 \mathrm{ppm}) \\
378.072 \mathrm{C}_{13} \mathrm{H}_{18} \mathrm{O}_{9} \mathrm{~N}_{2} \mathrm{~S} \\
360.0623 \mathrm{C}_{13} \mathrm{H}_{16} \mathrm{O}_{8} \mathrm{~N}_{2} \mathrm{~S} \\
352.0931 \mathrm{C}_{12} \mathrm{H}_{20} \mathrm{O}_{8} \mathrm{~N}_{2} \mathrm{~S} \\
334.082 \mathrm{C}_{12} \mathrm{H}_{18} \mathrm{O}_{7} \mathrm{~N}_{2} \mathrm{~S} \\
308.067 \mathrm{C}_{10} \mathrm{H}_{16} \mathrm{O}_{7} \mathrm{~N}_{2} \mathrm{~S} \\
228.1104 \mathrm{C}_{10} \mathrm{H}_{16} \mathrm{O}_{4} \mathrm{~N}_{2} \\
210.0996 \mathrm{C}_{10} \mathrm{H}_{14} \mathrm{O}_{3} \mathrm{~N}_{2}\end{array}$ & & \\
\hline
\end{tabular}


MAAs for which CID30 MS ${ }^{2}$ mass spectral data were not sufficient for the structural elucidation were studied using $\mathrm{MS}^{3}$ and $\mathrm{MS}^{4}$ fragmentation, which completed the description of their fragmentation routes.

Three main fragmentation routes starting either with a methyl radical loss, decarboxylation or dehydration were observed in most mass spectral data of elucidated MAAs. As it was illustrated in Figure 6, the multistage fragmentation of the novel MAA $m / z 411.1063$ permitted to propose a putative structure by monitoring the fragment ions produced in two main fragmentation pathways.

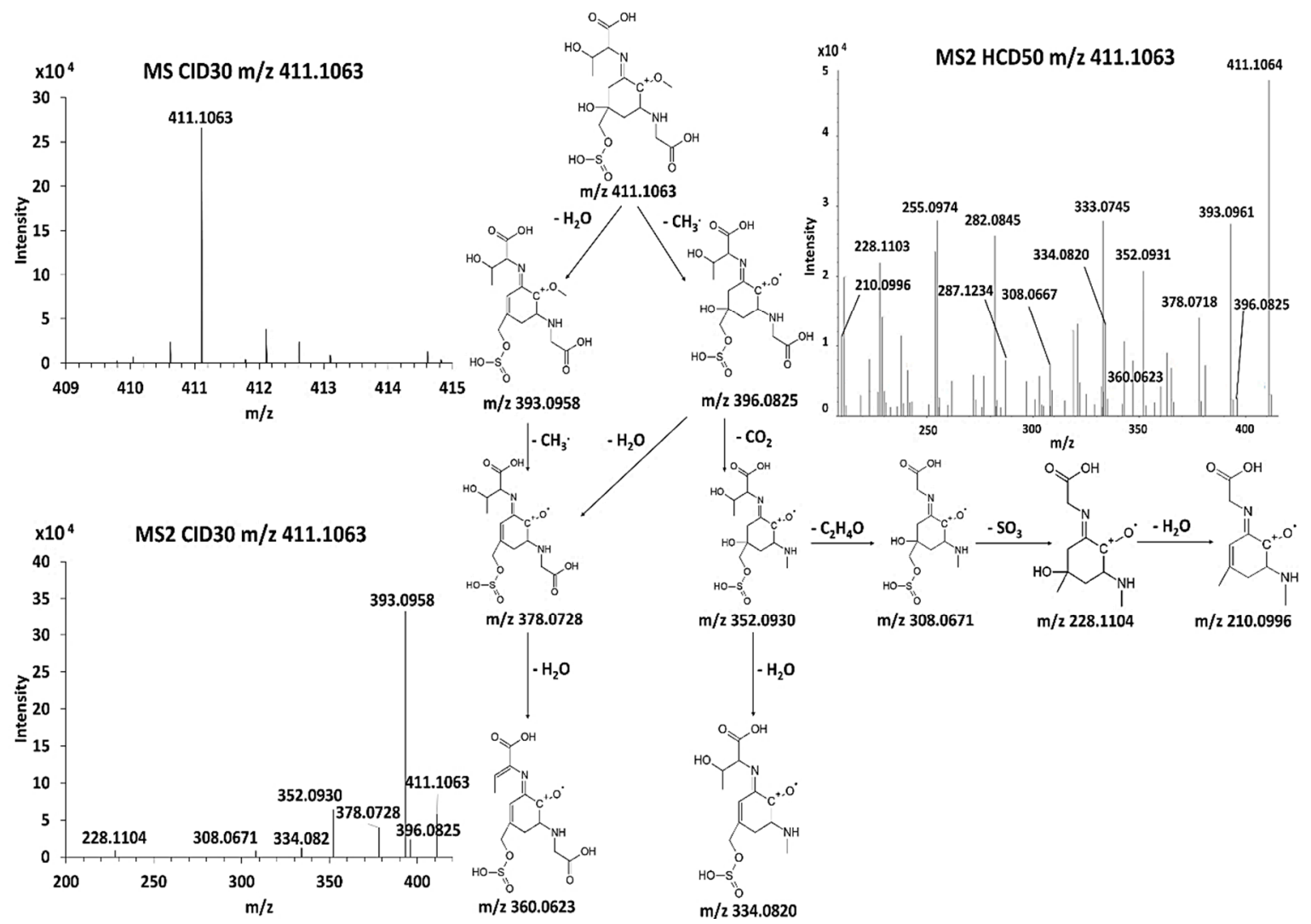

Figure 6. Structural elucidation of the novel MAAs $m / z 411.1063$ based on $\mathrm{MS}^{3} / \mathrm{MS}^{4}$ data collection.

The most intense fragment ion observed in the CID30 MS 2 spectrum of the candidate-MAA $m / z 411.1063$ was $m / z$ 393.0958. This result supported the hypothesis that the radical elimination pathway, specific to the MAAs, could compete with secondary fragmentation routes. The priority choice of a given fragmentation pathway depends on the presence and the number of functional groups on their amino acids substituents such as hydroxyl or carboxylic groups [29]. The observation of the neutral loss $\mathrm{SO}_{3}(79.95 \mathrm{Da})$ suggested for the first time the occurrence of sulfated MAAs. This neutral loss was also observed for the candidate-MAA $\mathrm{m} / \mathrm{z}$ 367.1164. The multistage fragmentation pathways of six other MAAs were detailed in Figure S6a-f.

The multistage fragmentation allowed the attribution to MAAs of hypothetical structures which are given in Table 6. 
Table 6. Proposed structures of seven candidate-MAAs detected in the model algae Gymnogongrus devoniensis. The following structures were selected with the greatest FISh scores by comparing experimental and in silico fragmentation.

\begin{tabular}{|c|c|c|}
\hline & Compound A & Compound B \\
\hline Name & $\begin{array}{l}\text { 2-\{[(3Z)-5-hydroxy-3-[(1-hydroxyethyl)imino]-5-(hydroxymethyl)- } \\
\text { 2-methoxycyclohex-1-en-1-yl]amino\}prop-2-enoic acid }\end{array}$ & $\begin{array}{l}\text { 3-hydroxy-2-(\{(3E)-5-hydroxy-5-(hydroxymethyl)-3-[(hydroxymethyl) } \\
\text { imino]-2-methoxycyclohex-1-en-1-yl\}amino)butanoic acid }\end{array}$ \\
\hline \multicolumn{3}{|l|}{ Structure } \\
\hline Monoisotopic mass (Da) & 300.1321 & 318.1425 \\
\hline \multirow[t]{2}{*}{ FISh score $(\%)$} & 62 & 53 \\
\hline & Compound C & Compound D \\
\hline Name & $\begin{array}{c}\text { 2-[(E)-\{3-[(1-carboxyethyl)amino]-5-hydroxy-5-(hydroxymethyl)- } \\
\text { 2-methoxycyclohex-2-en-1-ylidene\}amino]propanoic acid } \\
\text { HO }\end{array}$ & $\begin{array}{l}\text { 2-\{[(3E)-3-[(1-carboxyethyl)imino]-5-hydroxy-5-(hydroxymethyl)- } \\
\text { 2-methoxycyclohex-1-en-1-yl]amino\}-3-hydroxybutanoic acid } \\
\text { HO }\end{array}$ \\
\hline \multicolumn{3}{|l|}{ Structure } \\
\hline Monoisotopic mass (Da) & 330.1420 & 360.1522 \\
\hline FISh score $(\%)$ & 59 & 54 \\
\hline
\end{tabular}


Table 6. Cont.

\begin{tabular}{|c|c|c|}
\hline & Compound A & Compound B \\
\hline & Compound E & Compound F \\
\hline Name & $\begin{array}{l}\text { 2-\{(E)-[3-\{[carboxy(hydroxy)methyl]amino\}-5-hydroxy-5-(hydroxymethyl)- } \\
\text { 2-methoxycyclohex-2-en-1-ylidene]amino\}-3-hydroxybutanoic acid }\end{array}$ & $\begin{array}{l}\{[(3 \mathrm{E})-5 \text {-(hydroxymethyl)-3-[(2-hydroxypropyl)imino]- } \\
\text { 2-methoxy-5-(sulfinooxy)cyclohex-1-en-1-yl]amino\}acetic acid }\end{array}$ \\
\hline \multicolumn{3}{|l|}{ Structure } \\
\hline $\begin{array}{c}\text { Monoisotopic mass (Da) } \\
\text { FISh score }(\%)\end{array}$ & 362.1320 & 366.1096 \\
\hline \multicolumn{3}{|c|}{ Compound G } \\
\hline Name & $\begin{array}{l}\text { 2-[(E)-\{3-[(carboxymethyl)amino]-5-hydroxy-2-methoxy-5-[(sulfinooxy) } \\
\text { methyl]cyclohex-2-en-1-ylidene\}amino]-3-hydroxybutanoic acid }\end{array}$ & \\
\hline \multicolumn{3}{|l|}{ Structure } \\
\hline Monoisotopic mass (Da) & 410.0995 & \\
\hline FISh score $(\%)$ & 54 & \\
\hline
\end{tabular}


In particular, the fragmentation data allowed the identification of the functional substituents. Indeed, the R-group could be predicted on the structural modifications of the most common amino acids found in algal MAAs including decarboxylation, dehydration, carbonyl reduction and substitutions. This approach permitted to propose the classification of the eight candidate-MAAs into the palythine family, and the threonine, serine and alanine subfamilies [9]. The limitation of this assignment is the impossibility of the identification of the isomers present. Hence, more than one likely structure could be assigned for candidate-MAAs mentioned in Table S1. The detection of unknown MAAs is based on the fact that they have very similar chemical structures and produce many identical fragment ions. Therefore, the precise structure assignment may not be straightforward. The structural differences can be very small and the set of $\mathrm{MS}^{\mathrm{n}}$ fragment ions, as complete as it could be, may not be enough to propose unambiguous structures for all the MAAs detected, especially that many isomers occur. For instance, several structures can be proposed for their substituents on $\mathrm{C} 1$ and $\mathrm{C} 3$ carbons and imino and oxo-MAA isomers are common. To assure the highest quality of data interpretation, it is necessary to carry out a multistage fragmentation at different collision and energy modes to produce a larger set of fragment ions and distinct every isoform regarding the presence of different fragment ions. For every isomer, a FISh score was calculated to determine the highest percentage of fragment ions matching with those found in silico at a specific retention time. This permitted to suggest the most probable isomer. Concerning imino and oxo-MAA isomers, the latter can be easily distinguished by the detection of two characteristic fragment ions appearing specifically in imino-MAA MS ${ }^{2}$ HCD70 spectrum.

Please note that because of the possible coelution of different candidate-MAAs, isolation and sufficient purification of them could not be achieved to confirm the structures by NMR.

Therefore, LC using chiral stationary phases have become an essential tool in the determination of enantiomeric composition in complex samples [31]. The identification of one to several chiral centers on amino acid substituents or their derivatives in MAA structure could help to locate specific functional groups in their lateral chains. Nonetheless, chiral chromatography favored normal-phase using solvents incompatible with ESI interface in LC-MS ${ }^{n}$ applications. Although the increasing interest in developing chiral columns more versatile, the solvent and $\mathrm{pH}$ extraction and mobile phases turned out to be limiting factors in the identification of stereoisomers because of the possible enantioselective ion suppression or enhancement in ESI-MS analysis [32]. Moreover, most of the current analytical studies conducted still consist of targeted screening of enantiomeric compounds [31]. Hence the requirement to optimize analytical procedures to improve the characterization of stereoisomers with a broad range of physico-chemical properties in untargeted LC-MS ${ }^{n}$ analysis [33].

\subsection{Quantification}

Quantification of MAAs in algal extracts has usually been performed according to their molar extinction coefficient in HPLC-DAD $[13,18,20]$ or by HPLC-MS $[14,29]$ analysis making use of their MS signal and matching it with standards. As it is shown in Figure 7, analysis of the model algal extract Gymnogongrus devoniensis by HPLC with DAD detection revealed five major peaks in the UV trace.

These five peaks covered all the peaks observed in the XIC trace of the eight fragment ions for which retention times corresponded to retention times of MAAs detected in untargeted screening analysis. These results indicate that the HPLC-DAD resolution is insufficient to quantify the individual species and the results reported by these methods may suffer from the contribution of other MAAs than those targeted by the authors [20,34]. HPLC- MS/MS would be specific enough for quantification but as the sensitivity is a function of ionization, authentic standards of quantified MAAs are required, and they are not available.

It has to be emphasized that except for porphyra-334, shinorine and palythine for which calibration standards were available, and which were quantified by the method of standard additions, the results in Table 7 are purely estimative, based solely on the hypothesis that the electrospray MS response factor would be similar (within 10\%) for all the MAAs, as it was demonstrated for the three MAAs for which the standards were available. 


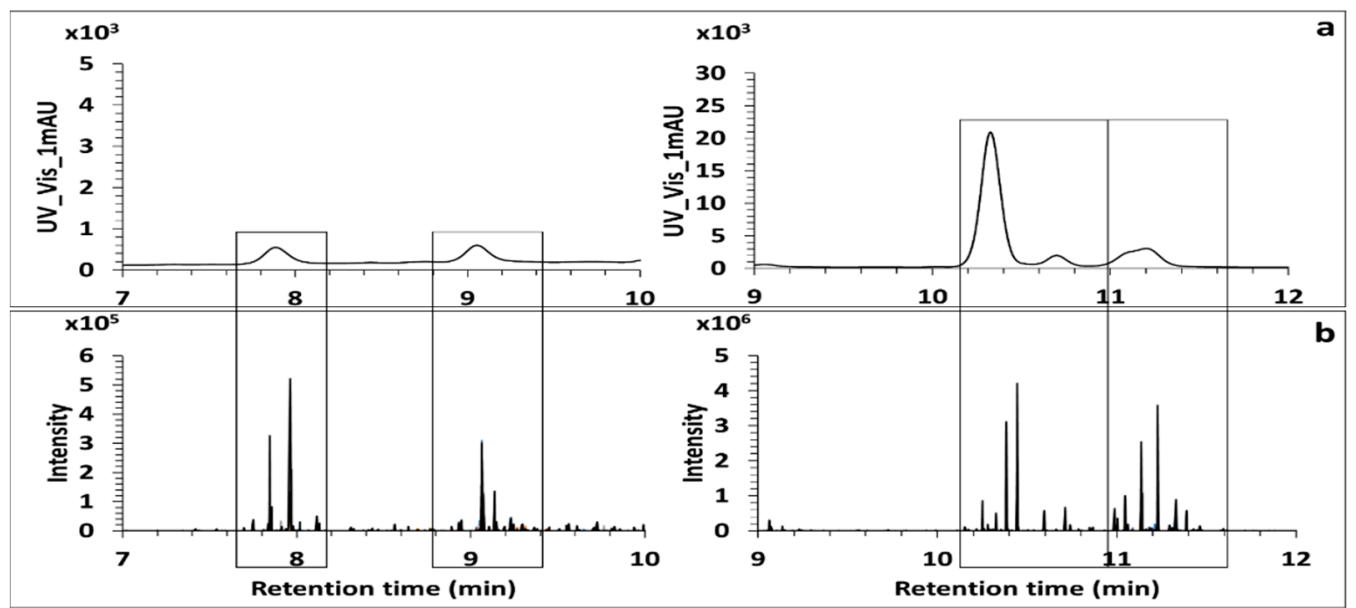

Figure 7. Screening of MAAs in the model alga Gymnogongrus devoniensis. UV Trace of MAAs recorded at (300-360) nm (a). XIC Trace $\mathrm{MS}^{2}$ of the set of eight fragment ions by ddMS ${ }^{2} / \mathrm{MS}^{3}$ untargeted analysis (b). All the peaks observed in the XIC trace $\mathrm{MS}^{2}$ indicate all the retention times for which MAAs were detected in the extract.

Table 7. Semi-quantitative analysis of MAAs detected in Gymnogongrus devoniensis. Amounts of MAA was estimated with an error of $10 \%$ regarding the signal intensities observed between the purified MAAs porphyra-334, shinorine and palythine injected at the same concentrations.

\begin{tabular}{|c|c|c|c|c|}
\hline MAAs & $\begin{array}{l}\text { Monoisotopic } \\
\text { Mass (Da) }\end{array}$ & Area $\operatorname{Max}\left(10^{5}\right)$ & Amounts ( $\left.\mu \mathrm{g} . \mathrm{g}^{-1} \mathrm{DW}\right)$ & Error $\left(\mu \mathrm{g} \cdot \mathrm{g}^{-1} \mathrm{DW}\right)$ \\
\hline Porphyra-334 & 346.1372 & 693 & 2100 & 0 \\
\hline Shinorine & 332.1214 & 85.2 & 430 & 0 \\
\hline Palythine & 244.1051 & 122 & 1530 & 0 \\
\hline Compound E & 362.1320 & 1.3 & 4 & 0.40 \\
\hline Aplysiapalythine-B & 272.1367 & 76.5 & 243 & 24.3 \\
\hline Palythinol & 302.1475 & 11.3 & 35.8 & 3.6 \\
\hline Mycosporine-2-glycine & 302.1112 & 3.6 & 11.3 & 1.1 \\
\hline Mycosporine methyl-amine threonine & 302.1475 & 2.4 & 7.7 & 0.8 \\
\hline Asterina-330 & 288.1316 & 187 & 593 & 59.3 \\
\hline Palythene/Usujirene & 284.1368 & 137 & 434 & 43.4 \\
\hline Compound B & 318.1425 & 1.6 & 5.2 & 0.5 \\
\hline Compound D & 360.1522 & 0.28 & 0.9 & 0.1 \\
\hline Mycosporine-glycine-valine & 344.1579 & 1.2 & 3.8 & 0.4 \\
\hline Compound C & 330.1420 & 1 & 3.4 & 0.3 \\
\hline Palythine glutamic-acid & 316.1266 & 6.3 & 19.8 & 2 \\
\hline Compound F & 366.1092 & 0.5 & 1.5 & 0.2 \\
\hline Palythine-serine & 274.1158 & 0.5 & 1.5 & 0.2 \\
\hline Compound G & 410.0990 & 0.5 & 1.6 & 0.2 \\
\hline Compound A & 300.1320 & 2.7 & 8.4 & 0.8 \\
\hline Aplysiapalythine-A & 302.1475 & 2 & 6.6 & 0.7 \\
\hline Mycosporine-glycine & 245.0899 & 0.9 & 2.9 & 0.3 \\
\hline
\end{tabular}

Interestingly, porphyra-334 and palythine were the most abundant in the model algae Gymnogongrus devoniensis as previously reported for algal species belonging to the Bangiales order [35]. Please note that an isolation process of shinorine was developed from this red algal specie [20].

\section{Applications}

The method developed was applied on three red algae (Gelidium sesquipedale, Halopithys incurva and Porphyra rosengurtii) and one brown alga (Cystoseira tamariscifolia) allowing the detection of tens MAAs reported in the literature, three MAAs detected and characterized here in the model alga Gymnogongrus devoniensis and four more novel candidate-MAAs reported on Table 8. 
Table 8. Candidate-MAAs detected in four different algal species using the Fragment Ion Search (FISh) in ddMS²/MS3 Untargeted Analysis and validated by subsequent Targeted Analysis.

\begin{tabular}{|c|c|c|c|c|c|c|c|c|}
\hline \multirow[b]{2}{*}{ MAAs } & \multirow[b]{2}{*}{ Formula } & \multirow[b]{2}{*}{ MW (Da) } & \multirow{2}{*}[\mathrm{M}+\mathrm{H}]{$^{+}(m / z)$} & \multirow[b]{2}{*}{ Retention Time (min) } & \multicolumn{4}{|c|}{ Number of Fragment Ions (/8) } \\
\hline & & & & & Porphyra rosengurtii & Gelidium sesquipedale & Halopithys incurva & $\begin{array}{c}\text { Cystoseira } \\
\text { tamariscifolia }\end{array}$ \\
\hline Palythine & $\mathrm{C}_{10} \mathrm{H}_{16} \mathrm{O}_{5} \mathrm{~N}_{2}$ & 244.1051 & 245.1124 & 11.16 & 8 & 8 & 6 & 7 \\
\hline Unknown & $\mathrm{C}_{12} \mathrm{H}_{24} \mathrm{O}_{3} \mathrm{~N}_{2}$ & 244.1786 & 245.1858 & 11.30 & 8 & & & \\
\hline Mycosporine-glycine & $\mathrm{C}_{10} \mathrm{H}_{15} \mathrm{O}_{6} \mathrm{~N}$ & 245.0891 & 246.0963 & 8.56 & & & 5 & \\
\hline Unknown & $\mathrm{C}_{10} \mathrm{H}_{17} \mathrm{O}_{6} \mathrm{~N}$ & 247.1051 & 248.1124 & 11.04 & & 8 & & \\
\hline Aplysiapalythine-B & $\mathrm{C}_{12} \mathrm{H}_{20} \mathrm{O}_{5} \mathrm{~N}_{2}$ & 272.1364 & 273.1437 & 9.01 & & 5 & & \\
\hline Palythine-serine & $\mathrm{C}_{11} \mathrm{H}_{18} \mathrm{O}_{6} \mathrm{~N}_{2}$ & 274.1157 & 275.1230 & 11.54 & 8 & 5 & & \\
\hline Palythene/Usujirene & $\mathrm{C}_{13} \mathrm{H}_{20} \mathrm{O}_{5} \mathrm{~N}_{2}$ & 284.1369 & 285.1438 & 7.82 & & & 8 & \\
\hline Unknown & $\mathrm{C}_{12} \mathrm{H}_{18} \mathrm{O}_{6} \mathrm{~N}_{2}$ & 286.1163 & 287.1236 & 10.54 & 7 & & & \\
\hline Asterina-330 & $\mathrm{C}_{12} \mathrm{H}_{20} \mathrm{O}_{6} \mathrm{~N}_{2}$ & 288.1315 & 289.1387 & 11.05 & 7 & 8 & 7 & \\
\hline Palythine-threonine & $\mathrm{C}_{12} \mathrm{H}_{20} \mathrm{O}_{6} \mathrm{~N}_{2}$ & 288.1321 & 289.1394 & 10.48 & 7 & & & \\
\hline Palythinol & $\mathrm{C}_{13} \mathrm{H}_{22} \mathrm{O}_{6} \mathrm{~N}_{2}$ & 302.1471 & 303.1544 & 10.20 & & & 6 & \\
\hline Palythine glutamic-acid & $\mathrm{C}_{13} \mathrm{H}_{20} \mathrm{O}_{7} \mathrm{~N}_{2}$ & 316.1266 & 317.1341 & 9.87 & 7 & & & \\
\hline Compound B & $\mathrm{C}_{13} \mathrm{H}_{22} \mathrm{O}_{7} \mathrm{~N}_{2}$ & 318.1424 & 319.1492 & 10.24 & 6 & & & \\
\hline Shinorine & $\mathrm{C}_{13} \mathrm{H}_{20} \mathrm{O}_{8} \mathrm{~N}_{2}$ & 332.1214 & 333.1286 & 10.53 & 8 & 8 & 5 & 7 \\
\hline Porphyra-334 & $\mathrm{C}_{14} \mathrm{H}_{22} \mathrm{O}_{8} \mathrm{~N}_{2}$ & 346.1371 & 347.1447 & 10.16 & 7 & & 7 & 6 \\
\hline Unknown & $\mathrm{C}_{14} \mathrm{H}_{22} \mathrm{O}_{8} \mathrm{~N}_{2}$ & 346.1370 & 347.1437 & 9.48 & & & 5 & \\
\hline Compound $\mathrm{F}$ & $\mathrm{C}_{13} \mathrm{H}_{22} \mathrm{O}_{8} \mathrm{~N}_{2} \mathrm{~S}$ & 366.1088 & 367.1161 & 11.03 & & 5 & & \\
\hline Compound G & $\mathrm{C}_{14} \mathrm{H}_{22} \mathrm{O}_{10} \mathrm{~N}_{2} \mathrm{~S}$ & 410.0991 & 411.1064 & 10.53 & 8 & & & \\
\hline
\end{tabular}

MAAs in bold letters correspond to those found in prior Targeted Analysis. MAAs identified in prior analysis of the model algal extract Gymnogongrus devoniensis were emphasized in bold letters. 
At least seven putative MAAs were detected in every red algal species. This was in contrast with the brown alga Cystoseira tamariscifolia in which only three MAAs were found, which confirms the specificity of the MAA synthesis in Rhodophyta taxa [34]. Notably, the 284.1369 Da mass was detected at different retention times (7.8-9.3min) in the alga Halopithys incurva suggesting the presence of both palythene and usujirene. However, their discrimination using tandem mass spectrometry or DAD detection remains limited due to their very close structures and molar extinction coefficients.

\section{Conclusions}

A set of eight fragment ions after data-dependent $\mathrm{MS}^{2} / \mathrm{MS}^{3}$ acquisition are a reliable bases for untargeted screening of mycosporines and MAAs in algal extracts. The developed HRAM-ESI-MS ${ }^{n}$ method permitted to discover unreported compounds and widen the MAA profiling of five algae regardless of their UV-absorbing properties without referring to existing databases or standards. Additional multistage fragmentation after fraction collection of algal extracts allowed the characterization of seven unreported MAAs without requiring their purification. The study reaches the limits in terms of the assignment of isomeric MAAs structures by the state-of-the-art MS technology. One of the upcoming challenges beyond this state-of-the-art is the identification of MAA stereoisomers. Indeed, MAAs have some (1-3) chiral carbons and may occur as many stereo-isomers with specific properties. The method responds to the increasing interest in the attribution to an algal MAA-profile for commercial health and cosmetic formula and bio-inspired materials.

Supplementary Materials: The following are available online at http://www.mdpi.com/2076-3921/9/12/1185/s1, Figure S1. (a) MS method developed for targeted screening approach of MAAs. (b) Flowchart of the Targeted Screening Approach of MAAs using an Orbitrap MS based on the Top3 MS 2 analysis. Figure S2 (a,b,c,d). XIC of MAAs (3ppm) in Porphyra rosengurtii, Gelidium sesquipedale, Halopithys incurva and Cystoseira tamarsiscifolia separated on the Zic-cHilic column. Figure S3. Fragmentation pathways of palythine (a) and porphyra-334 (b) obtained from their CID30 MS ${ }^{2}$ spectrum. Figure S4. CID30 MS ${ }^{2}$ spectrum of $m / z$ 301.1392. Characteristic neutral and radical losses were annotated between the fragment ions affected on the spectrum. Figure S5. MS ${ }^{2}$ spectum of asterina-330 ( $\mathrm{m} / \mathrm{z} 289.1394)$ obtained in targeted screening analysis with a stepped collision energy at HCD50 +/20. Figure S6 (a-f). Structural elucidation of six candidate-MAAs using ddMS ${ }^{2}$ spectra obtained in untargeted analysis and their multistage fragmentation after fraction collection. Table S1. Multiple structural predictions of three candidate-MAAs among the set of seven candidate-MAAs elucidated.

Author Contributions: M.P. carried out analytical method development with the help of S.G., experiments and wrote the original manuscript. S.C.M.F., and R.L. edited and revised the manuscript. All authors have read and agreed to the published version of the manuscript.

Funding: This work was financially supported by the grant given by le Conseil Régional Nouvelle-Aquitaine (no. 2018-23, CRNA, Bordeaux, France).

Acknowledgments: We thank Colin Mc Reynolds from Les Laboratoires de Biarritz (Biarritz, France) for his help in collecting the fresh algae and their identification.

Conflicts of Interest: The authors declare no conflict of interest.

\section{References}

1. Bedoux, G.; Hardouin, K.; Burlot, A.S.; Bourgougnon, N. Chapter Twelve-Bioactive Components from Seaweeds: Cosmetic Applications and Future Development. In Advances in Botanical Research; Bourgougnon, N., Ed.; Sea Plants; Academic Press: Cambridge, MA, USA, 2014; Volume 71, pp. 345-378.

2. Navarro, N.; Lopez Figueroa, F.; Korbee, N.; Bonomi Barufi, J.; Álvarez Gómez, F.; Coba, F. Mycosporine-like amino acids from red algae to develop natural uv sunscreens. In Sunscreens: Source, Formulations, Efficacy and Recommendations; Nova Science Publisher: Hauppauge, NY, USA, 2018; pp. 99-129.

3. Shick, J.M.; Dunlap, W.C. Mycosporine-Like Amino Acids and Related Gadusols: Biosynthesis, Accumulation, and UV-Protective Functions in Aquatic Organisms. Annu. Rev. Physiol. 2002, 64, 223-262. [CrossRef]

4. Bhatia, S.; Garg, A.; Sharma, K.; Kumar, S.; Sharma, A.; Purohit, A.P. Mycosporine and mycosporine-like amino acids: A paramount tool against ultra violet irradiation. Pharm. Rev. 2011, 5, 138-146. [CrossRef] [PubMed] 
5. De la Coba, F.; Aguilera, J.; Korbee, N.; de Gálvez, M.V.; Herrera-Ceballos, E.; Álvarez-Gómez, F.; Figueroa, F.L. UVA and UVB Photoprotective Capabilities of Topical Formulations Containing Mycosporine-like Amino Acids (MAAs) through Different Biological Effective Protection Factors (BEPFs). Mar. Drugs 2019, 17, 55. [CrossRef] [PubMed]

6. Chrapusta, E.; Kaminski, A.; Duchnik, K.; Bober, B.; Adamski, M.; Bialczyk, J. Mycosporine-Like Amino Acids: Potential Health and Beauty Ingredients. Mar. Drugs 2017, 15, 326. [CrossRef] [PubMed]

7. Claverie, M.; McReynolds, C.; Petitpas, A.; Thomas, M.; Fernandes, S.C.M. Marine-Derived Polymeric Materials and Biomimetics: An Overview. Polymers 2020, 12, 1002. [CrossRef]

8. Fernandes, S.C.M.; Alonso-Varona, A.; Palomares, T.; Zubillaga, V.; Labidi, J.; Bulone, V. Exploiting Mycosporines as Natural Molecular Sunscreens for the Fabrication of UV-Absorbing Green Materials. ACS Appl. Mater. Interfaces 2015, 7, 16558-16564. [CrossRef]

9. Wada, N.; Sakamoto, T.; Matsugo, S. Mycosporine-Like Amino Acids and Their Derivatives as Natural Antioxidants. Antioxidants 2015, 4, 603-646. [CrossRef]

10. Carreto, J.I.; Carignan, M.O. Mycosporine-Like Amino Acids: Relevant Secondary Metabolites. Chemical and Ecological Aspects. Mar. Drugs 2011, 9, 387-446. [CrossRef]

11. Rastogi, R.; Sonani, R.; Madamwar, D. UV Photoprotectants from Algae-Synthesis and Bio-Functionalities. In Algal Green Chemistry: Recent Progress in Biotechnology; Elsevier: Amsterdam, The Netherlands, 2017; pp. 17-38. ISBN 978-0-444-63784-0.

12. Carreto, J.I.; Carignan, M.O.; Montoya, N.G. A high-resolution reverse-phase liquid chromatography method for the analysis of mycosporine-like amino acids (MAAs) in marine organisms. Mar. Biol. 2005, 146, $237-252$. [CrossRef]

13. Llewellyn, C.A.; Airs, R.L. Distribution and Abundance of MAAs in 33 Species of Microalgae across 13 Classes. Mar. Drugs 2010, 8, 1273-1291. [CrossRef]

14. Hartmann, A.; Murauer, A.; Ganzera, M. Quantitative analysis of mycosporine-like amino acids in marine algae by capillary electrophoresis with diode-array detection. J. Pharm. Biomed. Anal. 2017, 138, 153-157. [CrossRef] [PubMed]

15. Hartmann, A.; Becker, K.; Karsten, U.; Remias, D.; Ganzera, M. Analysis of Mycosporine-Like Amino Acids in Selected Algae and Cyanobacteria by Hydrophilic Interaction Liquid Chromatography and a Novel MAA from the Red Alga Catenella repens. Mar. Drugs 2015, 13, 6291-6305. [CrossRef] [PubMed]

16. Orfanoudaki, M.; Hartmann, A.; Miladinovic, H.; Nguyen Ngoc, H.; Karsten, U.; Ganzera, M. Bostrychines A-F, Six Novel Mycosporine-Like Amino-Acids and a Novel Betaine from the Red Alga Bostrychia scorpioides. Mar. Drugs 2019, 17, 356. [CrossRef] [PubMed]

17. Cardozo, K.H.M.; Carvalho, V.M.; Pinto, E.; Colepicolo, P. Fragmentation of mycosporine-like amino acids by hydrogen/deuterium exchange and electrospray ionisation tandem mass spectrometry. Rapid Commun. Mass Spectrom. 2006, 20, 253-258. [CrossRef]

18. Carignan, M.O.; Cardozo, K.H.M.; Oliveira-Silva, D.; Colepicolo, P.; Carreto, J.I. Palythine-threonine, a major novel mycosporine-like amino acid (MAA) isolated from the hermatypic coral Pocillopora capitata. J. Photochem. Photobiol. B Biol. 2009, 94, 191-200. [CrossRef] [PubMed]

19. Sinha, R.P.; Klisch, M.; Gröniger, A.; Häder, D.-P. Mycosporine-like amino acids in the marine red alga Gracilaria cornea-Effects of UV and heat. Environ. Exp. Bot. 2000, 43, 33-43. [CrossRef]

20. De la Coba, F.; Aguilera, J.; Lopez Figueroa, F.; de Gálvez, M.; Herrera-Ceballos, E. Antioxidant activity of mycosporine-like amino acids isolated from three red macroalgae and one marine lichen. J. Appl. Phycol. 2008, 21, 161-169. [CrossRef]

21. Yuan, Y.V.; Westcott, N.D.; Hu, C.; Kitts, D.D. Mycosporine-like amino acid composition of the edible red alga, Palmaria palmata (dulse) harvested from the west and east coasts of Grand Manan Island, New Brunswick. Food Chem. 2009, 112, 321-328. [CrossRef]

22. Lalegerie, F.; Lajili, S.; Bedoux, G.; Taupin, L.; Stiger-Pouvreau, V.; Connan, S. Photo-protective compounds in red macroalgae from Brittany: Considerable diversity in mycosporine-like amino acids (MAAs). Mar. Environ. Res. 2019. [CrossRef]

23. Geraldes, V.; Jacinavicius, F.R.; Genuário, D.B.; Pinto, E. Identification and distribution of mycosporine-like amino acids in Brazilian cyanobacteria using ultrahigh-performance liquid chromatography with diode array detection coupled to quadrupole time-of-flight mass spectrometry. Rapid Commun. Mass Spectrom. 2020, e8634. [CrossRef] 
24. Pliego-Cortés, H.; Bedoux, G.; Boulho, R.; Taupin, L.; Freile-Pelegrín, Y.; Bourgougnon, N.; Robledo, D. Stress tolerance and photoadaptation to solar radiation in Rhodymenia pseudopalmata (Rhodophyta) through mycosporine-like amino acids, phenolic compounds, and pigments in an Integrated Multi-Trophic Aquaculture system. Algal Res. 2019, 41, 101542. [CrossRef]

25. Álvarez-Gómez, F.; Korbee, N.; Casas-Arrojo, V.; Abdala-Díaz, R.T.; Figueroa, F.L. UV Photoprotection, Cytotoxicity and Immunology Capacity of Red Algae Extracts. Molecules 2019, 24, 341. [CrossRef] [PubMed]

26. Whitehead, K.; Hedges, J.I. Analysis of mycosporine-like amino acids in plankton by liquid chromatography electrospray ionization mass spectrometry. Mar. Chem. 2002, 80, 27-39. [CrossRef]

27. Demarque, D.P.; Crotti, A.E.; Vessecchi, R.; Lopes, J.L.; Lopes, N.P. Fragmentation reactions using electrospray ionization mass spectrometry: An important tool for the structural elucidation and characterization of synthetic and natural products. Nat. Prod. Rep. 2016, 33, 432-455. [CrossRef] [PubMed]

28. Cardozo, K.H.M.; Vessecchi, R.; Carvalho, V.M.; Pinto, E.; Gates, P.J.; Colepicolo, P.; Galembeck, S.E.; Lopes, N.P. A theoretical and mass spectrometry study of the fragmentation of mycosporine-like amino acids. Int. J. Mass Spectrom. 2008, 273, 11-19. [CrossRef]

29. Cardozo, K.H.M.; Vessecchi, R.; Galembeck, S.E.; Guaratini, T.; Gates, P.J.; Pinto, E.; Lopes, N.P.; Colepicolo, P. A Fragmentation study of di-acidic mycosporine-like amino acids in electrospray and nanospray mass spectrometry. J. Braz. Chem. Soc. 2009, 20, 1625-1631. [CrossRef]

30. Whitehead, K.; Hedges, J.I. Electrospray ionization tandem mass spectrometric and electron impact mass spectrometric characterization of mycosporine-like amino acids. Rapid Commun. Mass Spectrom. 2003, 17, 2133-2138. [CrossRef]

31. Teixeira, J.; Tiritan, M.E.; Pinto, M.M.M.; Fernandes, C. Chiral Stationary Phases for Liquid Chromatography: Recent Developments. Molecules 2019, 24, 865. [CrossRef]

32. Evans, S.E.; Kasprzyk-Hordern, B. Applications of chiral chromatography coupled with mass spectrometry in the analysis of chiral pharmaceuticals in the environment. Trends Environ. Anal. Chem. 2014, 1, e34-e51. [CrossRef]

33. Camacho-Muñoz, D.; Petrie, B.; Castrignanò, E.; Kasprzyk-Hordern, B. Enantiomeric Profiling of Chiral Pharmacologically Active Compounds in the Environment with the Usage of Chiral Liquid Chromatography Coupled with Tandem Mass Spectrometry. Curr. Anal. Chem. 2016, 12, 303-314. [CrossRef]

34. Cardozo, K.; Marques, L.; Carvalho, V.; Carignan, M.; Pinto, E.; Marinho-Soriano, E.; Colepicolo, P. Analyses of photoprotective compounds in red algae from the Brazilian coast. Rev. Bras. Farmacogn. Braz. J. Pharmacogn. 2011, 21, 202-208. [CrossRef]

35. Boedeker, C.; Karsten, U. The occurrence of mycosporine-like amino acids in the gametophytic and sporophytic stages of Bangia (Bangiales, Rhodophyta). Phycologia 2005, 44, 403-408. [CrossRef]

Publisher's Note: MDPI stays neutral with regard to jurisdictional claims in published maps and institutional affiliations.

(C) 2020 by the authors. Licensee MDPI, Basel, Switzerland. This article is an open access article distributed under the terms and conditions of the Creative Commons Attribution (CC BY) license (http://creativecommons.org/licenses/by/4.0/). 